\title{
Eğimli Arazilerde Kaya Tutucu Toprakarme Duvarların Uygulanabilirliği ve Alternatif Kaya Islahı Çözümleriyle Karşılaştırılması: Kanlıpelit Örneği
}

\author{
Muhammet Çelik ${ }^{1}$, Mohammad Manzoor Nasery, ${ }^{2 *}{ }^{\circledR}$ \\ 1 il Afet ve Acil Durum Müdürlüğü, 61220, Ortahisar, Trabzon. \\ ${ }^{2}$ Karadeniz Teknik Üniversitesi, İnşaat Mühendisliği Bölümü, 61080, Ortahisar, Trabzon.
}

\section{Özet}

Toprakarme duvarlar kaya düşmesi afetini engellemek için kullanılan yüksek enerji sönümleme özelliğine sahip masif yapılardır. Toprakarme duvarların taban genişlikleri fazla olması nedeniyle kaya düşmesinin yaşandığ eğimli arazilerde uygulanmasinda çeşitli sıkıntılar doğmaktadır. Bu çalışmada, eğimli arazilerde toprakarme duvarların uygulanabilmesi için gelişstirilmiş çözüm örnek bir proje üzerine incelenmiştir. Buna göre eğimli arazide $6 \mathrm{~m}$ yüksekliğinde taş istinat duvarl ve dolgu yapılarak düz bir platform elde edilmesi ve toprakarme duvarın platform üzerine yapılması projelendirilmiştir. Platform yapılmadan önce 8 adet en kesit üzerine kaya düşme analizleri gerçekleştirilerek kayanın sıçrama yüksekliği, hız ve toplam kinetik enerji değerleri elde edilmiş, daha sonra platform imalatı bitirilmiş, aynı analizlerle elde edilen veriler karşılaştırılmıştır. Yapılan çalışmada oluşturulan bu platform kayaların sıçrama yükseklikleri değerlerini \%83, kinetik enerji değerlerini \%62 ve hız değerlerini \%42 oranında azaltmıştır. Çalıșmanın ikinci kısmında projelendirilen platform üzeri toprakarme duvarın maliyeti alternatif projelerin maliyetleri ile karşılaştırılmıştır. Buna göre 6 metre betonarme duvar arkasına dolgu ve üzerine 3 metre yüksekliğinde çelik bariyer yapılmasından \%60.8 oranında ve 6 metre yüksekliğinde çelik bariyer yapılmasından ise \%74.5 oranında daha az maliyetli olduğu görülmüştür. Yapılan çalışmanın sonunda; Çelik bariyerler, kaya çarpmaları sırasında boyca azalmaları, ilk yapım ve bakım onarım maliyetleri, ithal edilmeleri ve doğaya uyumu gibi çeşitli konularda toprakarme duvarlara göre dezavantajlidır. Bu nedenle oluşturulan platform üzerinde toprakarme duvar yapılmasının hem güvenlik açısından hem de maliyet açısından üstün bir ıslah yöntemi olduğu ortaya çıkmaktadır. Çalışma kapsamında gelişstirilen yöntem Trabzon İli Maçka İlçesi Güney Mahallesinde kaya ıslahı projesinde uygulanmıştır.

\section{Anahtar Sözcükler}

Doğal Afetler, Kaya Düşmesi, Toprakarme Duvarlar, Çelik Bariyerler, Kütle Hareketleri

\section{Applicability of the Reinforced Ground Embankments on Sloped Terrain and Their Comparison with Alternative Rockfall Protection System Solutions: Kanlıpelit Case}

\begin{abstract}
Reinforced ground embankments having high energy absorption capacity, which are being used as rockfall protection systems, are massive structures. Various problems arise in the application of reinforced ground embankments on sloped terrain, where rockfall occurs, because of it is high bottom width. In this study, a solution was improved for the application of reinforced ground embankments walls on sloping lands and was examined by implementing a pilot project. Additionally, it was planned to obtain a flat platform on inclined land with a $6 \mathrm{~m}$ high stone retaining wall and filling in order to construct the reinforced ground embankments wall on it. Initially rock fall analyses were performed on 8 cross sections in order to obtain bounce height, velocity and total kinetic energy values prior to constructing the platform. The same analysis was once again performed following the platform construction and the obtained data were compared. This platform has reduced $83 \%$ of the rocks' bounce heights, $62 \%$ of kinetic energy and $42 \%$ of velocity values. In the second part of the study, the cost of the reinforced ground embankments on the platform was compared with the costs of alternative projects. It was observed that constructing platform was $60.8 \%$ less expensive than a 6meter reinforced concrete wall with a 3 meter steel barrier and $74.5 \%$ cheaper than a 6meter steel barrier. Steel barriers are disadvantageous compared to the reinforced ground embankments walls in various aspect such as reduction in length during rock collisions, construction cost, maintenance costs, import and adaptation to nature. For the reasons above, we have concluded that construction of reinforced ground embankments wall over a constructed platform is a more efficient improvement solution in terms of both safety and cost. The developed solution within the scope of the study was applied in the rockfall protection project in Güney neighborhood, Maçka District of Trabzon Province.
\end{abstract}

$\underline{\text { Keywords }}$

Natural Disasters, Rockfall, Reinforced Ground Embankments, Steel Barrier, Mass Movement 


\section{Giriş}

Toprakarme duvarlar, madencilik, kavşak, köprü gibi yapıların taşıyıcı kenar ayakları, istinat yapıları, dere ve kaya 1slahları, askeri yapılar ve benzeri birçok uygulamada kullanılan yapılardır. Toprakarme duvarlar, kaya ıslahlarında genellikle çarpma hızı ve enerji kapasitesinin yüksekliğiyle birlikte maliyetinin düşük olması nedeniyle tercih edilmektedir. Toprakarme duvarların çeşitli üstün özellikleri olmasına karşılık tasarım özellikleri nedeniyle uygulama alanları kısıtlıdır. Özellikle taban alan genişliği nedeniyle eğimli arazilerde uygulanmalarında çeşitli sıkıntılar doğmaktadır. Kaya düşmesi, eğimli arazilerde (şev veya yamaçlarda) bulunan süreksizlik yüzeylerinde ayrılma olan kaya bloklarının yer çekimi etkisiyle alt kotlara doğru hareketi olarak tanımlanır (Varnes 1978; Hutchinson 1988). Kaya ıslahı çalışmaları olarak bariyerler, dayanma yapıları, hendekler, tepeler, çelik ağlar ile kaplama, kontrollü düşürmeler ve benzeri birçok yöntemler kullanılmaktadır. $\mathrm{Bu}$ yöntemlerde kayaların düşmeleri engellenmekte veya kontrollü düşürülerek tehlike yaratmasının önüne geçilmektedir (Turner ve Schuster 2012). Kaya ıslahı yöntemleri arasında seçim yapılırken emniyet ve ekonomi kriterleri değerlendirilerek en uygun yöntem belirlenir (Agliardi vd. 2009). Toprakarme duvarlar kaya ıslahlarında kullanılan yöntemler arasında gerek emniyet gerekse maliyet açısından en uygun yöntemlerden biridir. Özellikle büyük alanlarda yaşanan kaya düşme afetlerinde tüm alanda kontrollü kırım veya çelik ağlarla kaplama yöntemleri yerine düşme güzergâhlarına çelik bariyer veya toprakarme duvar yapılması daha iyi sonuçlar vermektedir. Çelik bariyerler ve toprakarme duvarlar, düşen kayanın çarpma hızı, kinetik enerji ve sıçrama yüksekliğine göre tasarlanmaktadır. Çelik bariyerler genellikle $25 \mathrm{~m} / \mathrm{sn}$ gibi belirli kaya çarpma hızına göre tasarlanmıştır. Daha fazla hızla gelen kayaların bariyerleri delme ihtimali bulunmaktadır. Toprakarme duvarlar çarpma hızı konusunda çelik bariyerlerden daha üstün yapılardır. Yapılan tam ölçekli arazi deneylerinde $30 \mathrm{~m} / \mathrm{sn}$ hıza dayanabildikleri tespit edilmiştir (Peila vd. 1998). Çelik bariyerler 500 kJ'den başlayarak binlerce kJ kapasitelere göre üretilmektedir. Kayaların düşerken kazandıkları kinetik enerji miktarı arttıç̧a çelik bariyerlerin birim maliyeti de artmaktadır. Ancak 5000 kJ üzeri tasarımlarda toprakarme duvarlar tercih edilmektedir (Descoeudres 1997). Toprakarme duvarlar kinetik enerjiyi sönümleme kapasiteleri oldukça yüksek yapılardır (Ronco vd. 2009). Ayrıca toprakarme duvarların maliyetlerini çok artırmayacak tercihler ile enerji sönümleme kapasiteleri artmaktadır. Örneğin kullanılan güçlendirme malzemesinin türü ve kalınlığı, dolgu tipi, duvar eni vb. özellikler toprakarme duvarların enerji kapasitesini oldukça fazla artırmaktadır (Peila vd. 2007). Çelik bariyerler ve toprakarme duvarların ortak tasarım kriterlerinden bir diğeri de kayaların sıçrama yükseklikleridir. Sıçrama yüksekliği artıkça çelik bariyer ve toprakarme duvarların yükseklikleri ve birim maliyetleri artmaktadır (Masuya vd. 2009). Tasarım için önemli konular olan doğaya uyum ve bakım onarım masrafları incelendiğinde toprakarme duvarlar her iki hususta da çelik bariyerlerden daha üstün yapılardır (Brunet vd. 2009). Ayrıca malzeme temini açısından da toprakarme duvarlar, çelik bariyerlerden üstündür. Çünkü duvarlarda kullanılan geogrid türleri genellikle kolay bulunabilen malzemelerdir, asıl kütleyi oluşturan toprak ve tuvenan/ariyet malzeme doğadan temin edilebilmektedir. Çelik bariyerlerde kullanılan malzemeler ise özellikle enerji sönümleyiciler ve kullanılan ağlar patentli ürünler olması nedeniyle konu ile ilgili araştırma geliştirme çalışmaları yapmış firmalar tarafından temin edilmektedir. Dünyada çelik bariyerle ilgili patentli ürüne sahip ülke sayısı oldukça azdır. Bu durum Türkiye dâhil birçok ülkenin çelik bariyerleri ithal etmesine neden olmaktadir.

Toprakarme duvarlar, kaya düşmelerini engelleyen masif yapılarıdır. Genellikle eğimli yüzeye sahip bu yapılarda, eğimin miktarı iki hususa göre belirlenir. Birinci husus yapının kendi kütlesini koruyabileceği şekilde olması ve ikincisi de gelen kaya kütlesinin çarpma sırasında yapının stabilitesini bozmaması ve oluşan deformasyonun sınırlı kalmasıdır. Ayrıca toprakarme duvarlar eğimli arazilerden gelen taşkın ve su ile birlikte taşınan malzemeleri biriktiren engeller olmamaları da istenilmektedir (Lambert ve Bourrier 2013). Karadeniz Bölgesi eğimli arazisi ve bol yağış alması nedeniyle kütle hareketlerinin oldukça sık rastlandığı bir bölgedir (Kaya vd. 2018). Bölgede kaya düşmelerinden etkilenen yerleşim birimleri kaynak kayalıkların alt kotlarında kurulmuş yerleşim birimleridir. Özellikle Doğu Karadeniz Bölgesi gibi düz arazinin az olduğu bölgelerde insanlar kayaların düşme güzergâhları üzerine yerleşim birimlerine oldukça sık rastlanılmaktadır (Şekil 1). Bu durum ıslah çalışmalarını da etkilemekte ve seçilecek yöntemler ile ilgili sorunlar oluşturmaktadır.

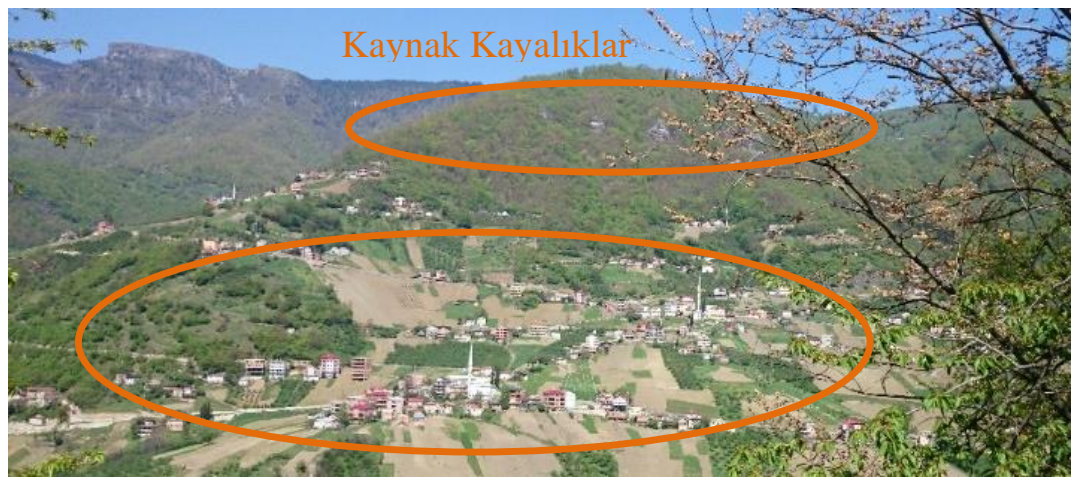

Şekil 1: Trabzon Düzköy İlçesi Gökçeler Mahallesi, eğimli ve kaya düşme güzergâhında bulunan konutlar 


\section{Yöntem}

Toprakarme duvar yapımı için belirli bir düz alan ihtiyaç olduğundan özellikle eğimli arazilerde uygulama sıkıntıları doğmaktadır. $\mathrm{Bu}$ çalışmada eğimli arazilerde toprakarme duvarların uygulanabilmesi için çözüm geliştirilmiş ve incelenmiştir. Geliştirilen çözümde, eğimli arazide ilk önce taş istinat duvar yapılması arkasına dolgu yapıldıktan sonra elde edilen düz platform üzerine toprakarme duvar oturtulması planlanmıştır (Şekil 2). Ayrıca bu çalışmanın 2. Bölümünde geliştirilen çözümün projelendirme aşamaları olan kaya düşme afetinin geçmişi, alanın harita çalışmaları, önlem yapısı yapılacak bölgedeki arazinin jeolojik ve jeofizik yöntemler ile incelenmesi ve kaya düşme analizleri ile ilgili detaylı bilgi verilmiştir. 3. Bölümde ise geliştirilen taş istinat duvar üzerine toprakarme duvar yapılması çözümüne alternatifleri olan betonarme duvar üzerine çelik bariyer ve sadece çelik bariyer önlem yapıları güvenlik ve ekonomik olarak karşılaştırılmıştır. Son bölümde ise geliştirilen çözüm için elde edilen sonuçlar verilmiştir. Çalışma kapsamında geliştirilen çözüm Trabzon İli Maçka İlçesi Güney Mahallesi Kanlıpelit Mevkiinde kaya 1slahı amacıyla uygulanmıştır.

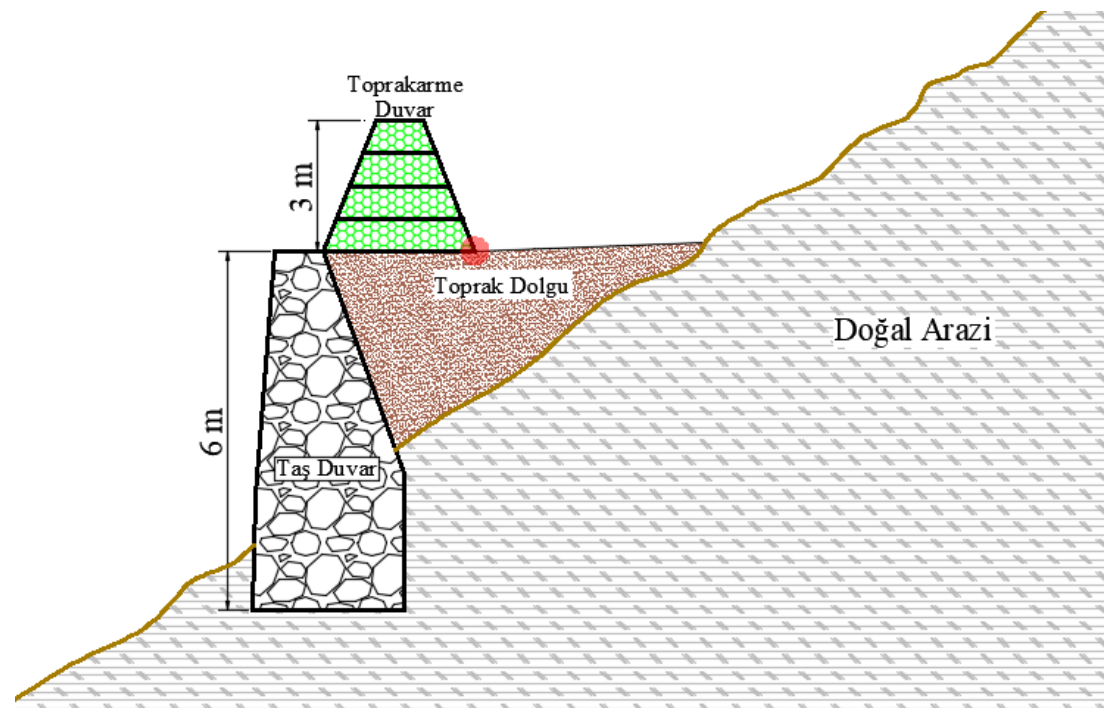

Şekil 2: Eğimli arazilerde toprakarme duvar uygulayabilmek için taş duvar ve dolgu ile geliştirilen çözüm detayı

\subsection{Kaya Düşme Afeti Yaşanan Alanın İncelenmesi}

Örnek alan, Trabzon İli Maçka İlçesi Güney Mahallesi Kanlıpelit mevkiinde bulunmaktadır. Alan Trabzon İline 27 km Maçka ilçesine $2.5 \mathrm{~km}$ uzaklıktadır. İlk vaka ihbarı 05.11.2009 tarihinde bir vatandaşın kaya düşmesi nedeniyle ağır yaralanması olayı olarak kayıt edilmiştir. Arazide yapılan incelemelerde çok daha öncelerden beri kaya düşmesi afeti yaşandığ1 anlaşılmaktadır. 03.03.2011 tarihinde bölgede ilk Jeolojik Etüt Raporu (JER) hazırlanmış ve 18 konut afete

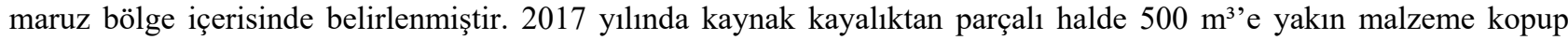
gelmiştir (Şekil 3). Bunun üzerine bölgede 19.04.2018 tarihli ikinci JER düzenlenmiş ve 25 konutun afete maruz bölge içerisinde olduğu tespit edilmiştir.
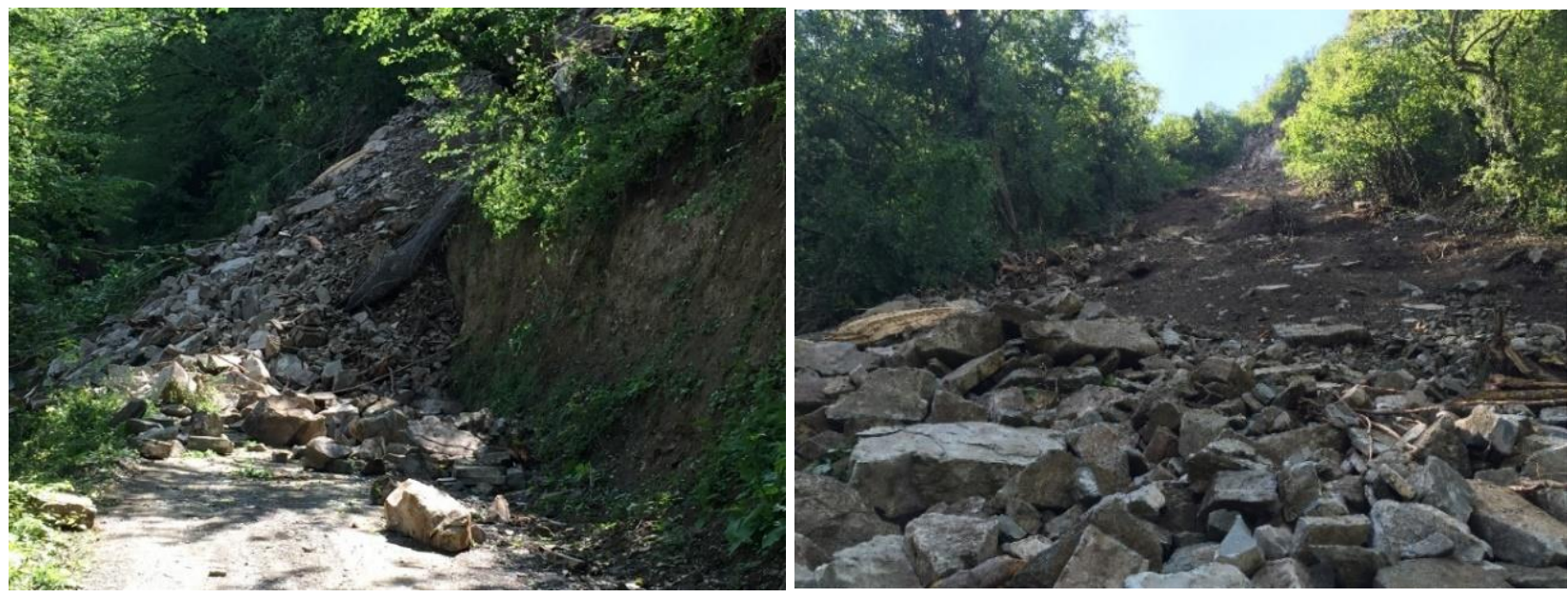

Şekil 3: 2017 yılı içerisinde bölgede yaşanan kaya düşmesi heyelanı 
Bölgede eğimin fazla olduğu kısımlarda ormanlık alan hâkim olup, alt kotlara doğru özellikle eğimin \%30’un altına düştüğü kısımlarda konutlar ve tarım arazileri bulunmaktadır. Orman içerisinde daha önce düşmüş kayalar ağaçlar tarafından tutulmuş olup tehlike arz etmektedir. Ayrıca JER'de belirtildiğine göre kaynak kayalıklarda tehlikeli süreksizliklere sahip $2000 \mathrm{~m}^{3}$ kayaya rastlanılmıştır. Bölgede JER'e göre imara ve iskâna kapatılmış alan Şekil 4'te verilmiştir.

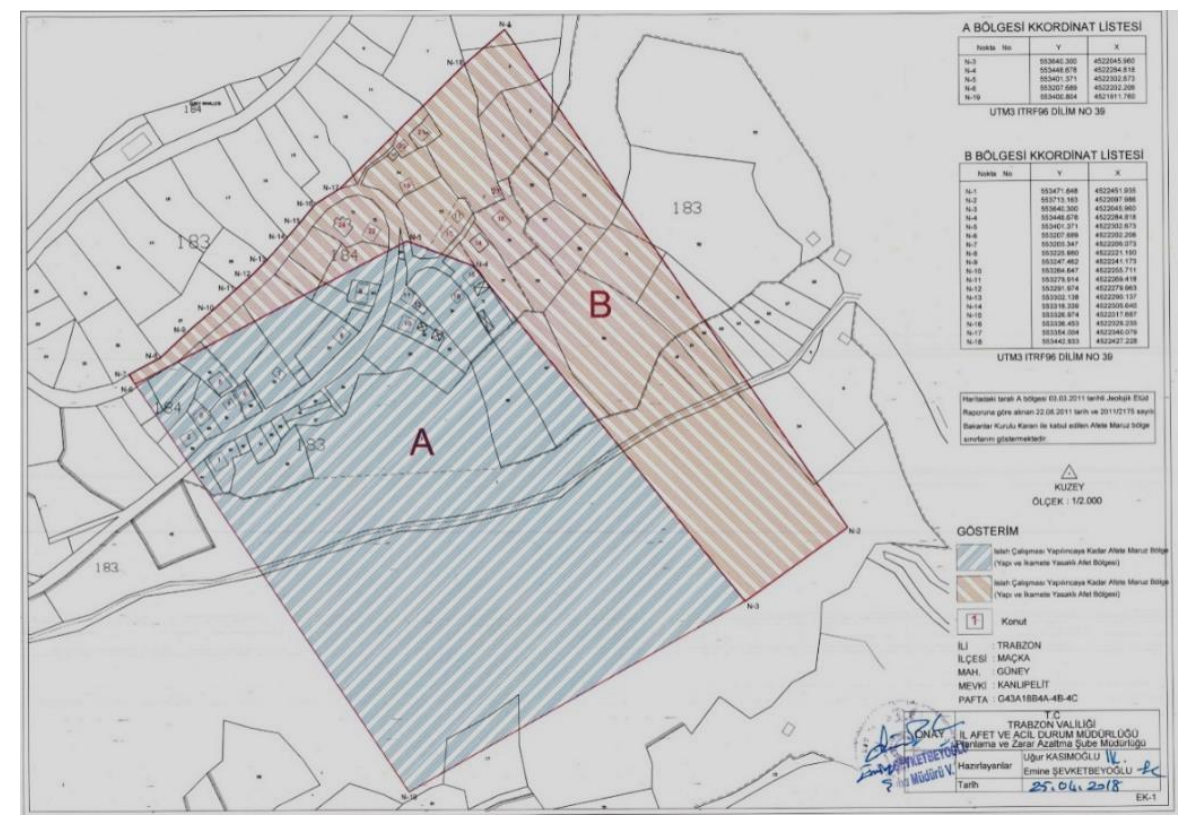

Şekil 4: Farklı tarihlerde hazırlanmış 2 JER'e göre imara ve iskâna kapalı alan

\subsection{Alanın Harita Çalışması}

Kaya ıslahı projelerinde uygun modelin tespiti ve hesabı için en önemli verileri harita çalışmaları oluşturmaktadır. Harita çalışmaları sayesinde düşen kayaların gidebilecekleri güzergâhlar, sıçrama yükseklikleri, hız ve kazanacakları enerji ile ilgili tahminlerde bulunulabilmektedir. Bu nedenle harita çalışmaları oldukça titiz yapılmalıdır (Çelik vd. 2016). Şekil 5'de bölgeden alınmış ölçümlere göre hazırlanmış harita görülmektedir. Harita eş yükselti eğrileri, kaynak kayalar ve konutları içermektedir. Ayrıca kaya düşme analizleri için bu haritadan belirlenmiş olan en kritik 8 güzergâh kesiti alınarak kaya düşme analizlerinde altlık olarak kullanılmıştır.

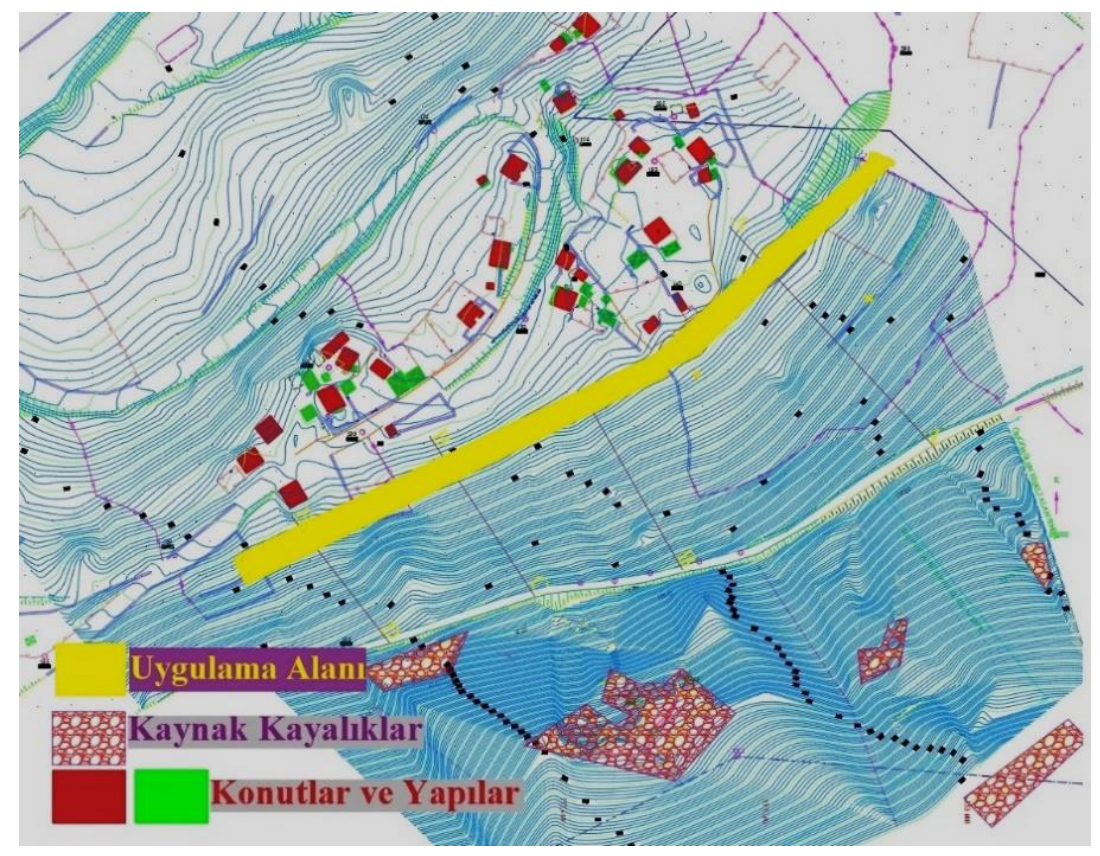

Şekil 5: Bölgede hazırlanmış eş yükselti eğrisi harita konutlar ve kaynak kayalıklar 


\subsection{Alanda Jeolojik ve Geoteknik Çalışmalar}

Kaya ıslah önlem yapısının yapılacağı alanın zemin parametrelerini belirlemek için arazide gözlemsel 3 adet araştırma çukuru açılmıştır (Şekil 6). Araştırma çukurlarının yerleri, jeolojik yapının farklılaştığı, topoğrafyanın değiştiği ve yapılacak olan duvar güzergahı boyunca homojen olmasına göre belirlenmiştir. Temel zeminini oluşturan birimi tanımak ve taşıma gücünü saptamak için inceleme alanında açılan AÇ-1, AÇ-2 ve AÇ-3 nolu araştırma çukurlarından alınan zemin ve kaya numuneleri üzerinde Atterberg limitleri, doğal birim hacim ağırlık, su muhtevası, direkt kesme kutusu deneyleri ve nokta yükü dayanım deneyi yapılmıştır. Ayrıca inceleme alanındaki yamaç molozundan alınan zemin numuneleri üzerlerinde elek analizi deneyleri ve Atterberg limitleri deneyleri yapılarak birimlerin fiziksel parametreleri tespit edilmiştir (Tablo 1). Arazi çalışmaları sırasında elde edilen zemin numuneleri, arazide gözle tanımlanmakta ve arazi cetvellerine işlenmekte, laboratuvarda ise ASTM D-2487-69 "Birleştirilmiş Zemin Sınıflandırması" şartnamesine uygun olarak sınıflandırılmaktadır. ASTM D-2487-69 "Birleştirilmiş Zemin Sınıflandırması" standartlarına göre elek analizi deneyine tabi tutulan zemin numunelerinin GP-GM (üniform çakıl ve az silt), GW (iyi derecelendirilmiş çakıl) ve SC (killi kum ve az çakıl) zemin sınıflarında yer aldığı belirlenmiştir (Moistures 1982).

Çalışmada kullanılan kesme kutusu deneyinin amacı sıkılıkları farklı olan kohezyonlu veya kohezyonsuz zemin numunesine kesme etkisi uygulayarak zemin numunesinin kayma parametrelerini, kayma direncini (c) ve kayma açısını ( $\phi)$ bulmaktır. Bu deney kohezyonlu ve kohezyonsuz zeminler için uygun olmakla birlikte, daha ziyade kumlar için uygundur. Açılan araştırma çukurundan alınan numunelerin kayma dayanım parametrelerini belirlemek için kesme kutusu deneyi yapılmış ve elde edilen sonuçlar Tablo 2'de verilmiştir. Kesme kutusu deneyleri (ASTM 2011) standardına uygun olarak 50,100 ve $200 \mathrm{kN} / \mathrm{m}^{2}$ normal gerilmeler altında yapılmıştır.

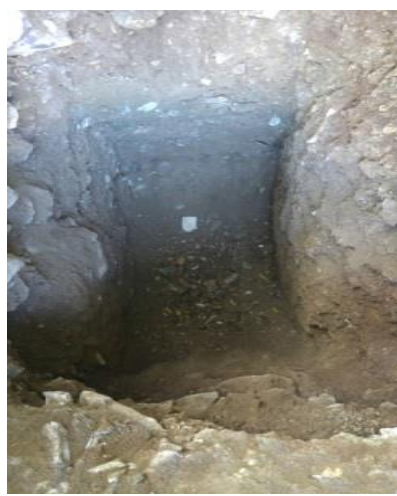

AÇ-1

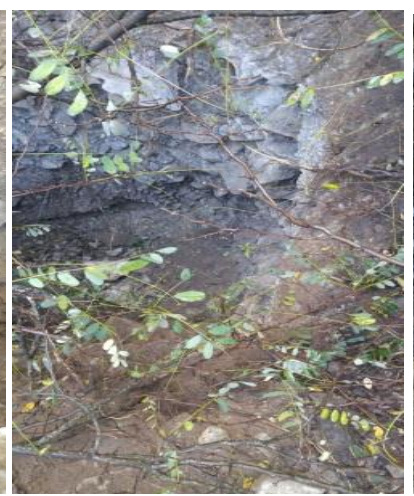

AÇ-2

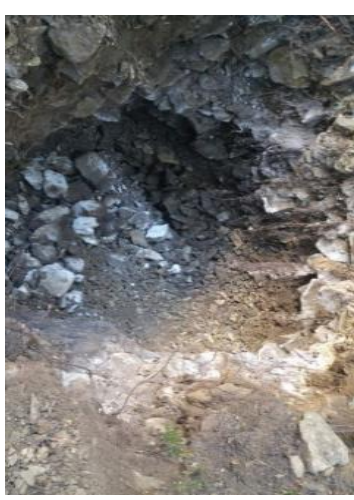

AÇ-3

Şekil 6: Arazi çalışması sırasında açılan üç adet araştırma çukuru görünümleri

Tablo 1: Inceleme alanında yer alan ince taneli zeminlere ait fiziksel özellikleri

\begin{tabular}{|c|c|c|c|c|c|c|c|c|c|c|}
\hline \multirow[b]{2}{*}{ 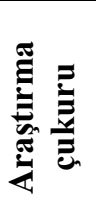 } & \multirow[b]{2}{*}{$\widehat{\overparen{E}}$} & \multicolumn{5}{|c|}{ Elek analizi } & \multicolumn{3}{|c|}{ Atterberg limitleri } & \multirow[b]{2}{*}{ 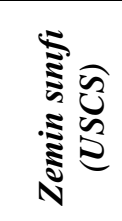 } \\
\hline & & $\begin{array}{l}0 \\
0\end{array}$ & 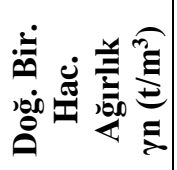 & صี & $\begin{array}{l}\stackrel{0}{Z} \\
+ \\
+\end{array}$ & ¿̊. & $\begin{array}{l}\text { Likit } \\
\text { Limit }\end{array}$ & $\begin{array}{c}\text { Plastik } \\
\text { Limit } \\
\%\end{array}$ & $\begin{array}{c}\text { Plastisite } \\
\text { İndisi } \\
\%\end{array}$ & \\
\hline$A C ̧-1$ & 5.00 & 4.60 & 1.64 & Yamaç Molozu & 84.7 & 8.1 & $N P$ & $N P$ & $N P$ & GP-GM \\
\hline$A C ̧-2$ & 5.00 & 4.10 & 1.63 & Yamaç Molozu & 89.1 & 4.8 & $N P$ & $N P$ & $N P$ & $G \boldsymbol{W}$ \\
\hline$A C ̧-3$ & 5.00 & 9.90 & 1.66 & Yamaç Molozu & 32.9 & 24.6 & 32.20 & 19.34 & 12.90 & $S C$ \\
\hline
\end{tabular}

Tablo 2: Kesme kutusu deneylerin değerleri

\begin{tabular}{|c|c|c|c|c|}
\hline $\begin{array}{c}\text { Kuyu } \\
\text { No }\end{array}$ & $\begin{array}{c}\text { Derinlik } \\
(\mathbf{m})\end{array}$ & $\begin{array}{c}\text { Kohezyon } \\
(\mathbf{k g} / \mathbf{c m} 2)\end{array}$ & $\begin{array}{c}\text { İçsel Sürtünme Açısı } \\
(\mathbf{\Phi})\end{array}$ & $\begin{array}{c}\text { Zemin } \\
\text { Sınıf }\end{array}$ \\
\hline AÇ-1 & 5.00 & $\mathrm{c}=0.01$ & $\Phi=32^{\circ}$ & GP-GM \\
\hline AÇ-2 & 5.00 & $\mathrm{c}=0.01$ & $\Phi=32^{\circ}$ & GW \\
\hline AÇ-3 & 5.00 & $\mathrm{c}=0.16$ & $\Phi=25^{\circ}$ & SC \\
\hline
\end{tabular}


İnceleme alanında bulunan kayaların özelliklerini saptamak için açılan AÇ-1 ve AÇ-2 nolu araştırma çukurlarından alınan kaya numuneleri üzerinde kaya mekaniği laboratuvarında nokta yükleme deneyi yapılarak kayaların mekanik özellikleri elde edilmiştir (Tablo 3). AÇ-1 ve AÇ-2'den alınan kayaçlar üzerinde yapılan nokta yükleme deneyinden elde edilen tek eksenli basınç dayanımına göre yer alan kaya birimleri, literatüre göre düşük dayanımlı kaya sınıfına girmektedir (Deer ve Miller 1966).

Tablo 3: Nokta yükleme deneyi sonucu elde edilen kayaların mekanik özellikleri

\begin{tabular}{|c|c|c|c|c|}
\hline Deney Adı & $\begin{array}{c}\text { Örnek } \\
\text { Derinliği (m) }\end{array}$ & $\begin{array}{c}\text { Nokta Yükü } \\
\text { İndisi }\left(\mathbf{k g} / \mathbf{c m}^{2}\right)\end{array}$ & $\begin{array}{c}\text { Tek Eksenli } \\
\text { Sıkışma Dayanımı } \\
\boldsymbol{\sigma c}\left(\mathbf{k g} / \mathbf{c m}^{2}\right)\end{array}$ & $\begin{array}{c}\text { Kayaç } \\
\text { Sınıflaması }\end{array}$ \\
\hline $\begin{array}{c}\text { Nokta Yükleme } \\
\text { Deneyi (SK-1) }\end{array}$ & 5.00 & 26.00 & 312.00 & R2-Zayıf Kaya \\
\hline $\begin{array}{c}\text { Nokta Yükleme } \\
\text { Deneyi (SK-2) }\end{array}$ & 5.00 & 28.00 & 336.00 & R2-Zayıf Kaya \\
\hline
\end{tabular}

\subsection{Alanda Jeofizik Çalışmalar}

Kaya ıslahı önlem yapısı yapılacak hattın yerini belirlemek için jeolojik çalışmaya ek olarak jeofizik yöntemler ile de zeminin özellikleri belirlenmiştir. Buradaki amaç hem jeolojik çalışmaları teyit etmek hem de hat boyunca zemindeki tabakalaşmanın net bir şekilde ortaya konulmasını sağlamaktır. Çünkü yapılacak olan $6 \mathrm{~m}$ taş istinat duvarının arkasındaki dolgunun ve toprakarme duvarın ağrılığı oldukça fazla olacağından yer seçimi oldukça önemli olmaktadır. Çalışma alanında hat boyunca uygun görülen iki profil boyunca karşılıklı atışlı "Sismik Kırılma ve MASW” ölçümü yapılmıştır.

\subsubsection{Sismik Kırılma (Refraction) Yöntemi}

Yüzeyde herhangi bir kaynak yardımıyla oluşturulan dalga ara yüzeye (tabaka sınırı) gelir ve Huygens prensibine göre ara yüzey boyunca her bir nokta yeni bir yarı küresel elastik dalga merkezi olmaktadır. Bu dalga hızı P dalgası yayılımı için $\mathrm{V}_{\mathrm{p}}$ hızıyla ve $\mathrm{S}$ dalgası için $\mathrm{V}_{\mathrm{s}}$ hızıyla ortam içinde hareket etmektedir. Bu hareket arazi uygulamalarında $\mathrm{P}$ ve $\mathrm{S}$ dalga hızlarının sismik kırılma yöntemiyle tespit edilerek sahaya ait tabakaların elastik parametreleri hakkında bilgi edinilmesi sağlanmıştır. Bu çalışmada, 2000 Model OYO GEOSPACE marka 24 kanallı McSEIS-SX 1125M model sismograf ve RTC marka 4.5Hz'lik düşey bileşen jeofonlar kullanılmıştır (Şekil 7).

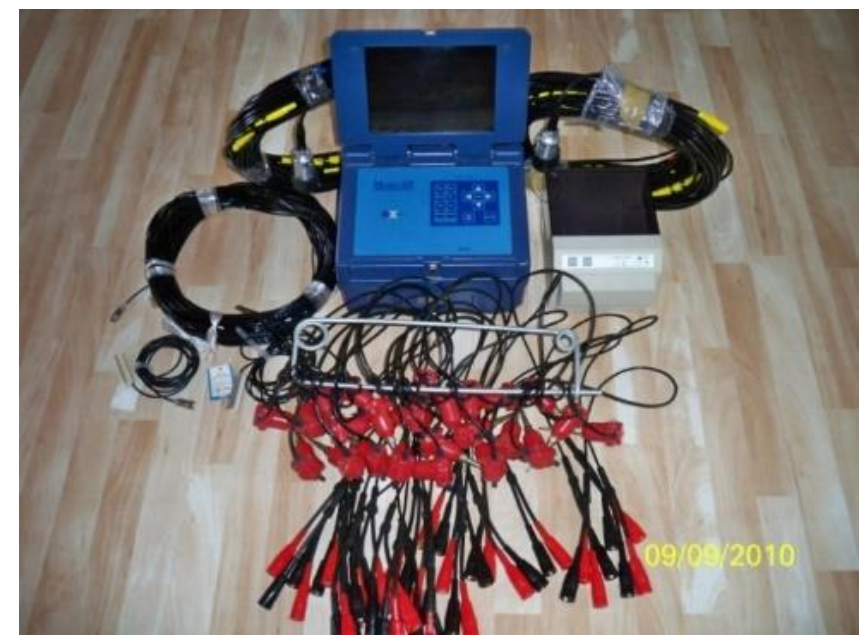

Şekil 7: Jeofizik çalışmada kullanılan sismik cihazın görünümü

\subsubsection{MASW Yöntemi}

S-tipi sismik hız analizi için "Multi Channel Analysis of Surface Waves" (MASW) tekniği kullanılmıştır. Ayrıca veri toplama aşamasında 4,5 Hz doğal frekansa sahip jeofonlar kullanılmıştır. Bu yöntem P-tipi saha kaydında mevcut Rayleigh tipi yüzey dalgalarının düzlem-dalga bileşenlerine ayrılarak analiz edilmesi ilkesine dayanmaktadır. Analiz sonucu elde edilen faz hızı - frekans spektrumundan dispersiyon ergisi tespit edilir ve bir başlangıç modelini takiben iteratif olarak sonuç S-tipi hız - derinlik modelini oluşturmaktadır. Jeofizik çalışmada toplamda iki serim yapılmıştır. Serim ise MASW yöntemi ile hat boyunca alınan bir ölçüme denilmektedir. 
Serim-1 için jeofon aralığı 4 metre, ofset mesafesi 8 metre ve toplam serim uzunluğu 60 metre, Serim-2 için jeofon aralığ 4 metre, ofset mesafesi 8 metre ve toplam uzunluk 60 metre seçilmiştir. Serim-1 için ilk tabakayı oluşturan birimin P dalgası hızı $365 \mathrm{~m} / \mathrm{sn}, \mathrm{S}$ dalgası hızı $77 \mathrm{~m} / \mathrm{sn}$ olarak tespit edilmiştir. İkinci tabakanın P dalga hızı $525 \mathrm{~m} / \mathrm{sn}, \mathrm{S}$ dalga hızı $135 \mathrm{~m} / \mathrm{sn}$, üçüncü tabakanın P dalga hızı $1745 \mathrm{~m} / \mathrm{sn}, \mathrm{S}$ dalga hızı $382 \mathrm{~m} / \mathrm{sn}$ olarak tespit edilmiştir. Serim-2 için ilk tabakayı oluşturan birimin P dalgası hızı $365 \mathrm{~m} / \mathrm{sn}$, S dalgası hızı $107 \mathrm{~m} / \mathrm{sn}$ olarak tespit edilmiştir. İkinci tabakanın P dalga hızı $805 \mathrm{~m} / \mathrm{sn}, \mathrm{S}$ dalga hızı $196 \mathrm{~m} / \mathrm{sn}$ olarak tespit edilmiştir. Üçüncü tabakanın P dalga hızı $1255 \mathrm{~m} / \mathrm{sn}, \mathrm{S}$ dalga hızı $408 \mathrm{~m} / \mathrm{sn}$ olarak tespit edilmiştir. İnceleme alanında yapılan 2 adet serim hattına ait elde edilen sonuç eğrileri Şekil 8'de $\mathrm{P}$ ve $\mathrm{S}$ dalga hızları ile derinlikleri ise Tablo 4'te verilmiştir.
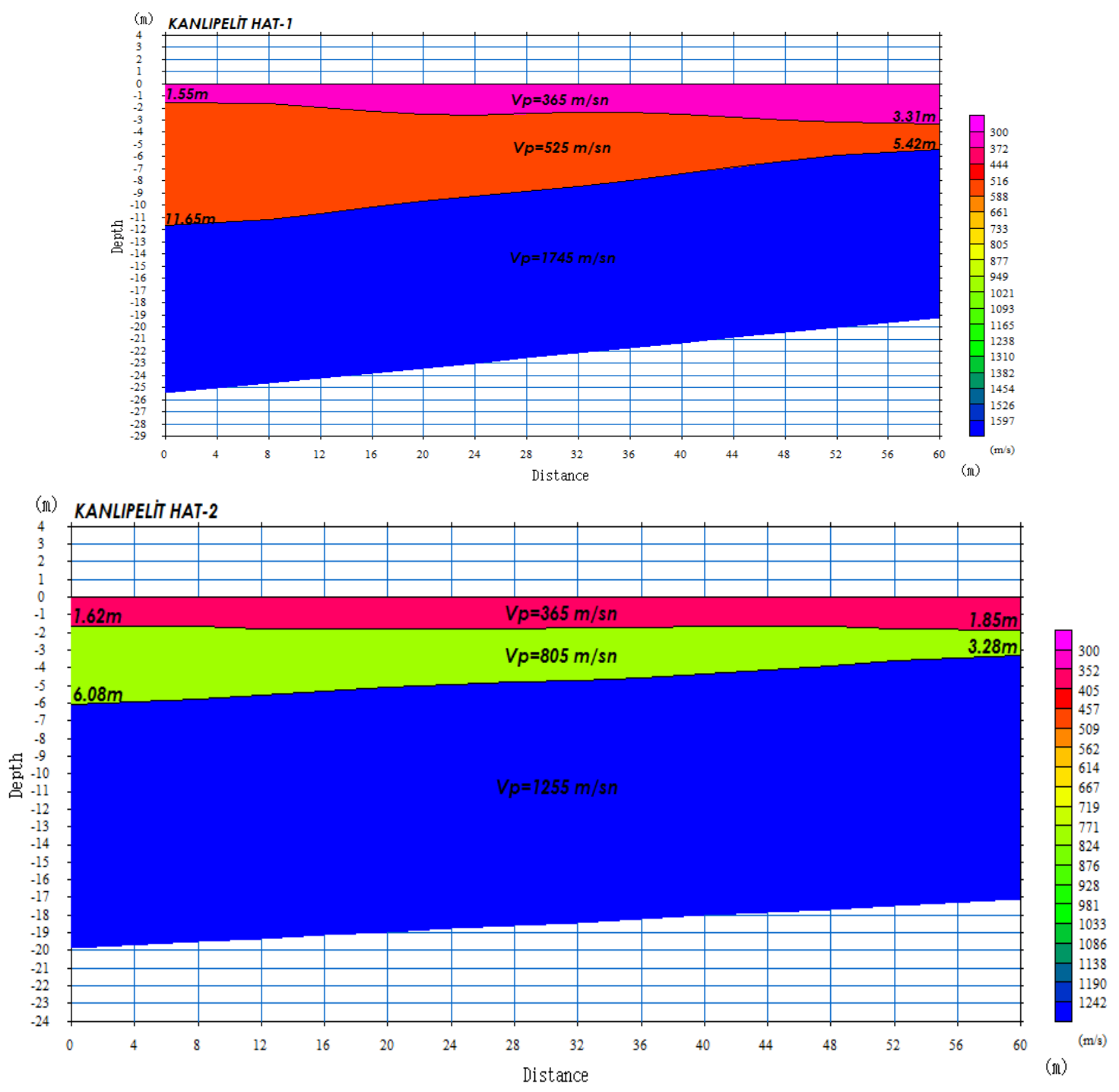

Şekil 8: Jeofizik yöntemler ile elde edilen zemin tabakalarını gösteren eğriler

Tablo 4: $P$ ve S Dalgası hızları ve derinlikleri

\begin{tabular}{|c|c|c|c|c|c|c|c|}
\hline \multirow{2}{*}{ Serim No } & \multirow{2}{*}{ Tabaka No } & \multirow{2}{*}{$\begin{array}{c}\text { P Dalgası Hızı } \\
(\mathbf{m} / \mathbf{s n})\end{array}$} & $\begin{array}{c}\text { S Dalgası Hızı } \\
(\mathbf{m} / \mathbf{s n})\end{array}$ & \multicolumn{2}{|c|}{ Kalınlı (m) } & \multicolumn{2}{c|}{ Derinlik (m) } \\
\cline { 5 - 9 } & & $365 \mathrm{~m} / \mathrm{sn}$ & $77 \mathrm{~m} / \mathrm{sn}$ & 1.55 & 3.31 & - & - \\
\hline \multirow{3}{*}{ Serim-1 } & 1 & $525 \mathrm{~m} / \mathrm{sn}$ & $135 \mathrm{~m} / \mathrm{sn}$ & 10.10 & 2.11 & 1.55 & 3.31 \\
\cline { 2 - 8 } & 2 & $1745 \mathrm{~m} / \mathrm{sn}$ & $382 \mathrm{~m} / \mathrm{sn}$ & - & - & 11.65 & 5.42 \\
\cline { 2 - 9 } & 3 & $365 \mathrm{~m} / \mathrm{sn}$ & $107 \mathrm{~m} / \mathrm{sn}$ & 1.62 & 1.85 & - & - \\
\hline \multirow{3}{*}{ Serim-2 } & 1 & $805 \mathrm{~m} / \mathrm{sn}$ & $196 \mathrm{~m} / \mathrm{sn}$ & 4.46 & 1.43 & 1.62 & 1.85 \\
\cline { 2 - 9 } & 2 & $1255 \mathrm{~m} / \mathrm{sn}$ & $408 \mathrm{~m} / \mathrm{sn}$ & - & - & 6.08 & 3.28 \\
\hline
\end{tabular}




\subsubsection{Elastisite (Young) Modülü}

Bir doğrultudaki gerilmelerin, deformasyonlara oranı olarak tanımlanan elastisite modülü, jeofizik yöntemle elde edilen zeminin mekanik özelliklerini belirlemesindeki en önemli parametrelerden biri olmaktadır. Keçeli (1990), yaptığı çalışmalarda elastisite modülüne göre zeminleri sınıflandırmıştır (Tablo 5). Elastisite modülü bağıntı 1 ve 2 yardımıyla farklı zemin tabakaları için hesaplanabilmektedir. Buna göre çalışmada yapılan 2 Serim için elastisite modülleri hesaplanarak zemin dayanım sınıfları elde edilmiştir (Tablo 6).

Tablo 5: Elastisite modülü değerlerine göre zemin ya da kayaçların dayanım (Keçeli 1990)

\begin{tabular}{|c|c|}
\hline Elastisite Modülü $\left(\mathbf{E}, \mathbf{~ k g} / \mathbf{c m}^{\mathbf{2}}\right)$ & Dayanım \\
\hline$<1000$ & Çok zayıf \\
\hline $1000-5000$ & Zayıf \\
\hline $5000-10000$ & Orta \\
\hline $10000-30000$ & Sağlam \\
\hline$>30000$ & Çok Sağlam \\
\hline
\end{tabular}

$E=2 \mu(1+\mu) \mathrm{kg} / \mathrm{cm}^{2}$

$E=\frac{G\left(3 V_{p}^{2}-V_{s}^{2}\right)}{V_{p}^{2}-V_{s}^{2}} c m^{2}$

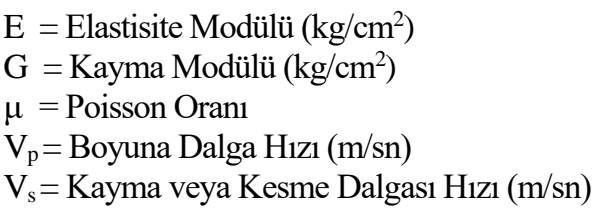

Tablo 6: Serim-1 ve Serim-2'ye ait Elastisite Modülü değerleri ve zemin dayanım sınıfları

\begin{tabular}{|c|c|c|c|}
\hline \multirow{2}{*}{ Serim No } & Tabakalar & $\begin{array}{c}\text { Elastisite Modülü } \\
\left(\mathbf{E}, \mathbf{k g} / \mathbf{c m}^{2}\right)\end{array}$ & Dayanım \\
\hline \multirow{3}{*}{ Serim-1 } & 1. Tabaka & $237 \mathrm{~kg} / \mathrm{cm}^{2}$ & Çok Zayıf \\
\cline { 2 - 4 } & 2. Tabaka & $791 \mathrm{~kg} / \mathrm{cm}^{2}$ & Çok Zayıf \\
\cline { 2 - 4 } & 3. Tabaka & $8611 \mathrm{~kg} / \mathrm{cm}^{2}$ & Orta \\
\hline \multirow{3}{*}{ Serim-2 } & 1. Tabaka & $450 \mathrm{~kg} / \mathrm{cm}^{2}$ & Çok Zayıf \\
\cline { 2 - 4 } & 2. Tabaka & $1860 \mathrm{~kg} / \mathrm{cm}^{2}$ & Zayıf \\
\cline { 2 - 4 } & 3. Tabaka & $8838 \mathrm{~kg} / \mathrm{cm}^{2}$ & Orta \\
\hline
\end{tabular}

\subsection{Kaya Düşme Analizleri}

Kayanın düşme sırasında yapacağı hareket ile ilgili analizler bilgisayar destekli analiz programları kullanılarak yapılmıştır. Buna göre düşmesi muhtemel kaya boyutunun belirlenmesi için arazide daha önce düşmüş veya düşmesi muhtemel kayalarda gözlemsel incelemeler yapılmıştır. Gözlemler ve tespit edilen süreksizlikler neticesinde en büyük boyuttaki kayanın yaklaşık 5 ton ağırlıkta olduğu tespit edilmiştir. Kaya düşme analizlerinde Rocfall (2013) programı kullanılarak 40 farklı güzergâh için 150 olasılıklı düşme senaryoları analiz edilmiştir. Kesitlerin zemin özellikleri güvende kalacak şekilde kritik değerlerde seçilmiştir. Buna göre genel olarak bitki ve molozdan oluşan zemin ve bazı bölgelerde de kaya zeminine göre senaryo hazırlanmıştır (Rocscience Inc. 2013). Kaya düşme analizlerinde normal sürtünme katsayısı (Rn) 0,3-0,35 teğetsel sürtünme katsayısı (Rt) 0,80-0,85 ve kaya bloklarına ilk hız değeri $1 \mathrm{~m} / \mathrm{sn}$. olarak girilmiştir. Elde edilen sonuçlarda en kritik sonuçları veren 8 tanesi seçilmiştir. Buna göre, ilk önce arazi doğal halinden alınmış 8 en kesit üzerine, her bir kesit için 150 olasılıklı düşme senaryosu oluşturularak toplamda 1200 farklı kaya düşme analizi gerçekleştirilmiştir. Elde edilen analiz sonuçları ve muhtemel sıçrama yüksekliklerinin detayları güzergâh boyunca Şekil 9'da verilmiştir. Ayrıca koruma yapısı düşünülen bölgedeki sıçrama yüksekliği, hız ve toplam kinetik enerji değerleri Tablo 7'de verilmiştir. Daha sonra aynı kesitlere çalışma kapsamında geliştirilmiş olan çözüme uygun olarak taş istinat duvarı ve arkasında dolgu ile oluşturulan platform tanımlanarak aynı analizler tekrar edilmiştir. Bu analizlere ait güzergâh boyunca sıçrama yüksekliklerinin simülasyonu Şekil 10’da verilmiştir. 
Şekil 10'de sıçrama yüksekliklerin grafikleri üzerine ölçekli olarak geliştirilen istinat duvarı üzerine toprakarme kaya tutucu duvar işlenmiş̧tir. Buradan da görüldüğü gibi yapılan analizlerde herhangi bir kaya koruma yapısını aşamamıştır. Analizlerden elde edilen hız, toplam sıçrama yüksekliği değerleri ve toplam kinetik enerji değerleri Tablo 8'de verilmiştir. Sonraki bölümde, geliştirilen çözümün sıçrama yüksekliğine, hıza ve toplam kinetik enerjiye etkileri karşılaştırılmıştır.

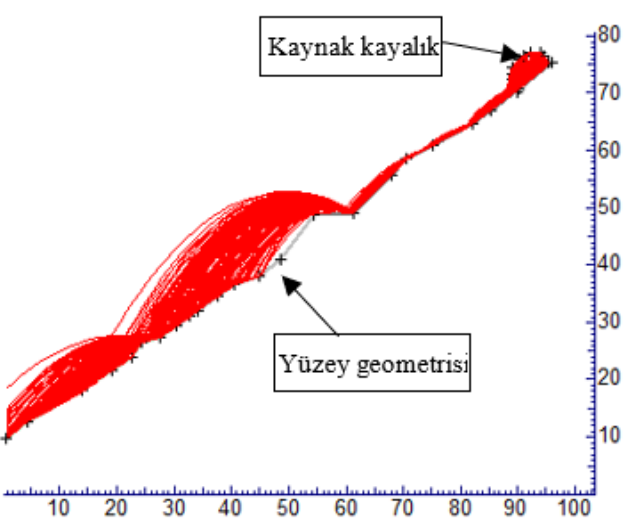

(i)

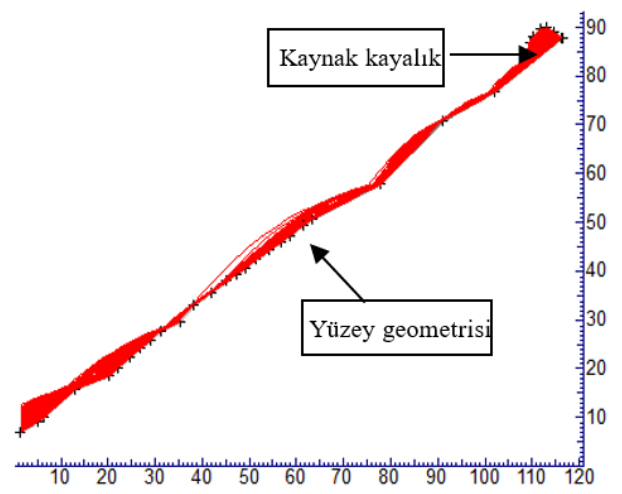

(iii)

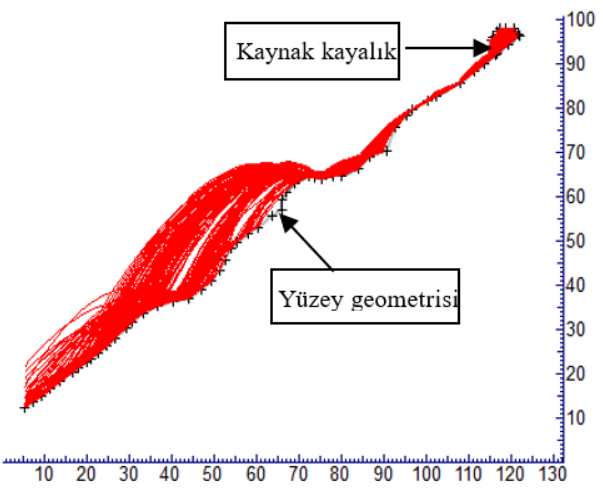

(v)

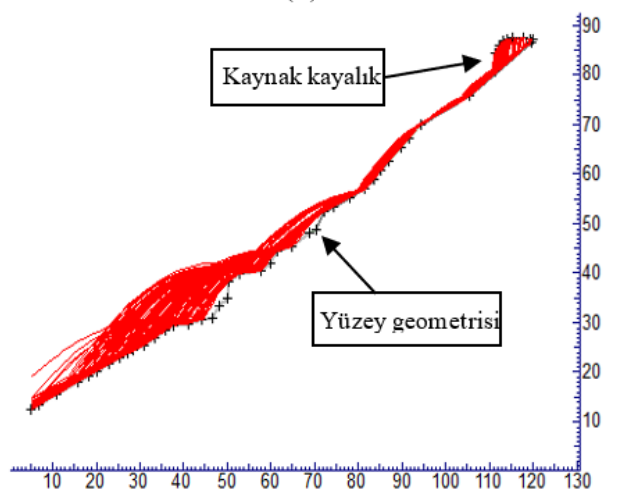

(vii)

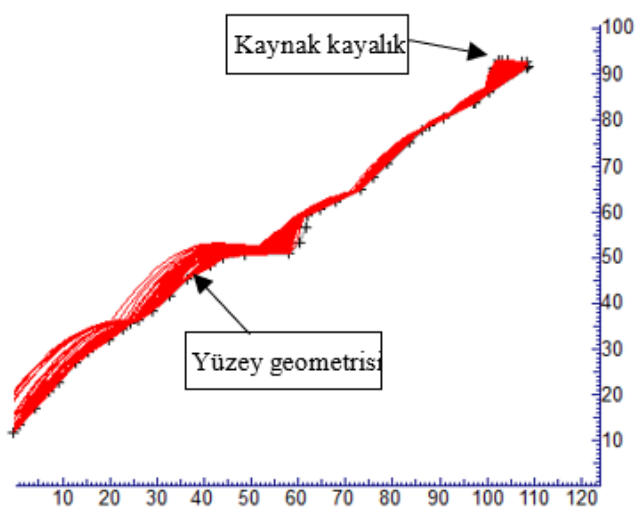

(ii)

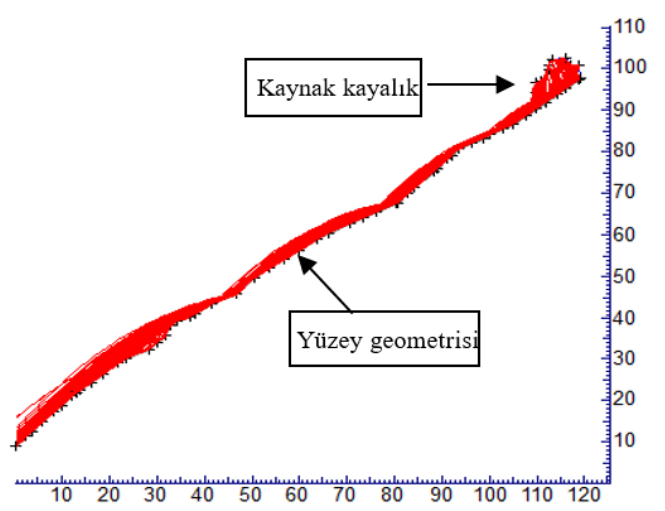

(iv)

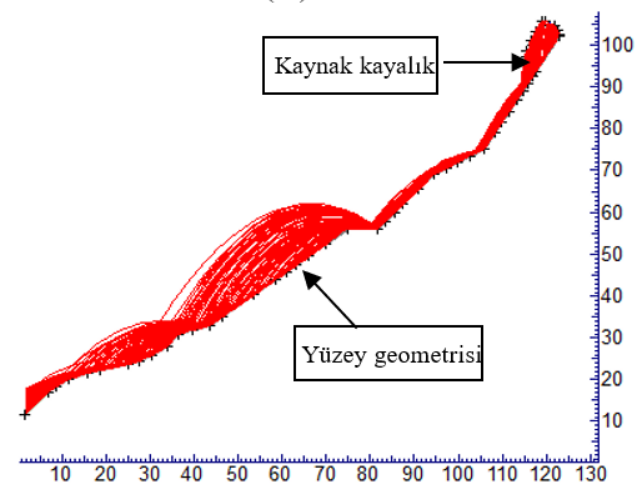

(vi)

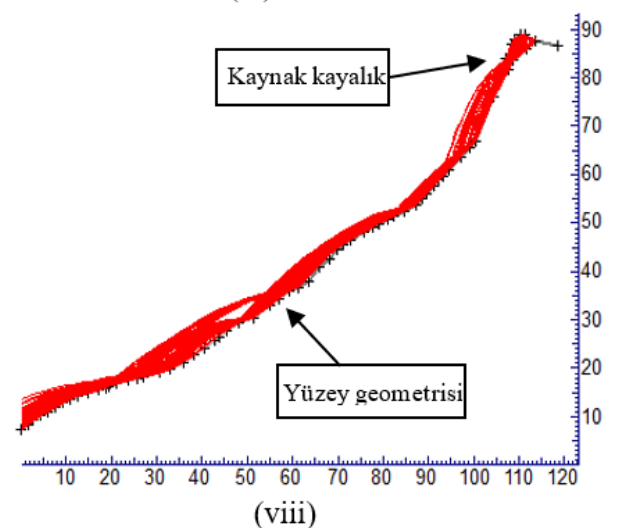

(viii)

Şekil 9: Arazinin doğal halinden alınmış kritik güzergâhlara kaya düşsme analizlerinde kayaların muhtemel hareketleri 


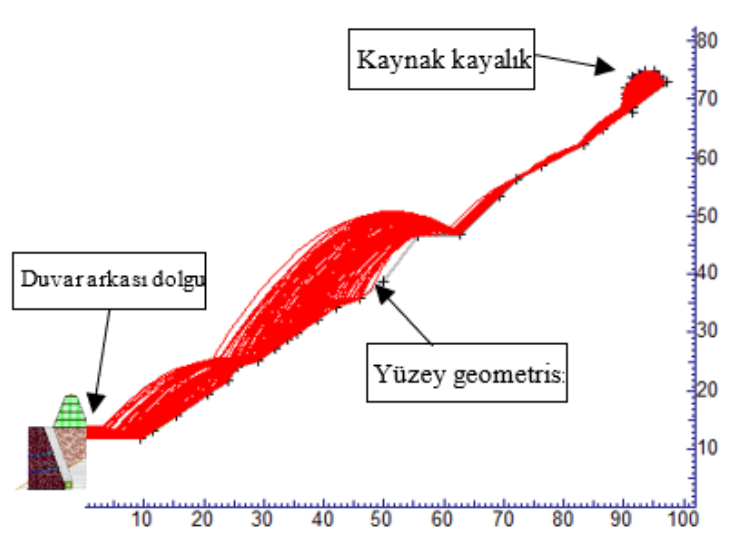

(i)

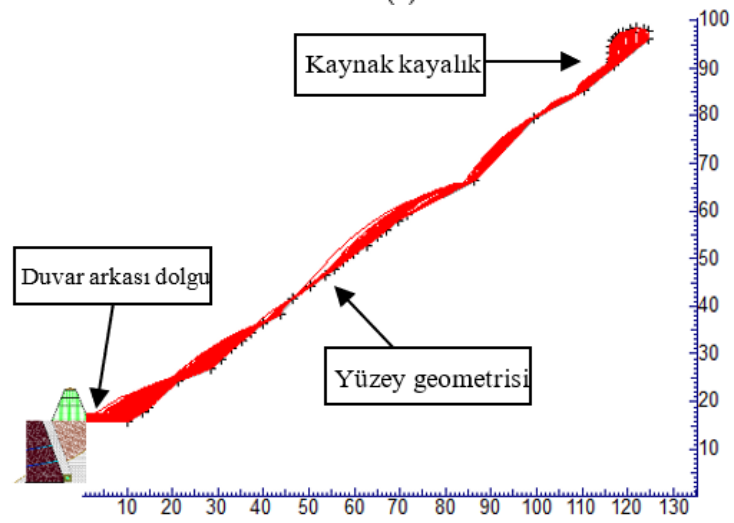

(iii)

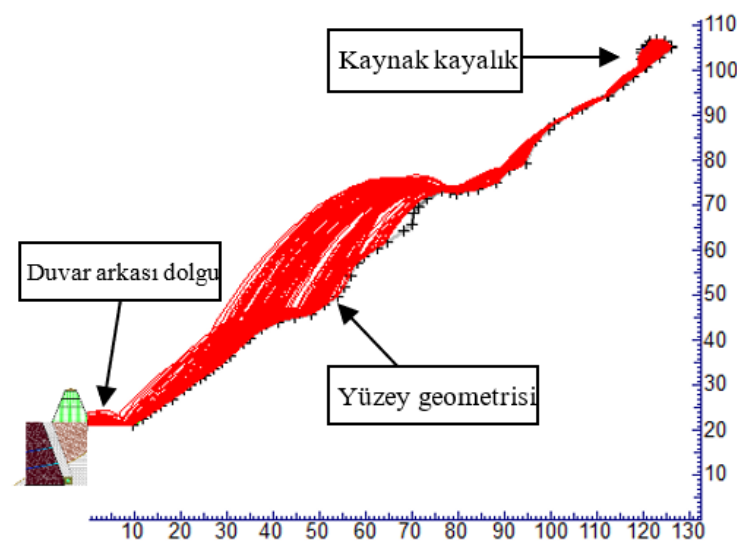

(v)

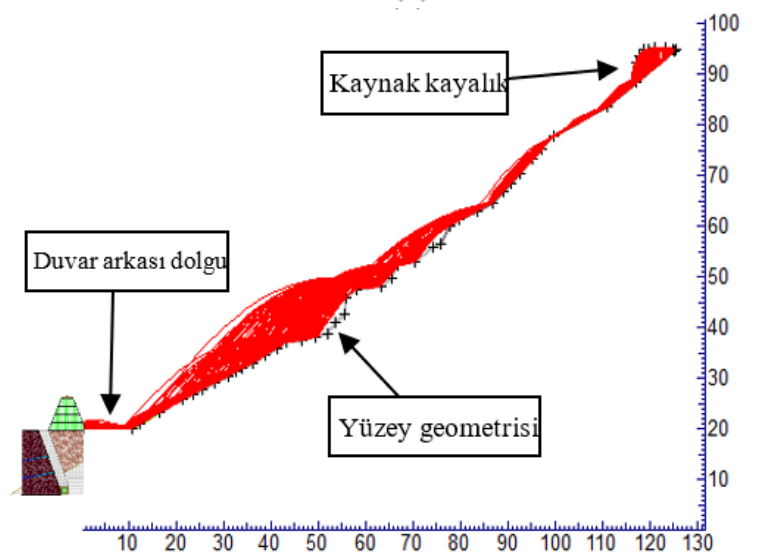

(vii)

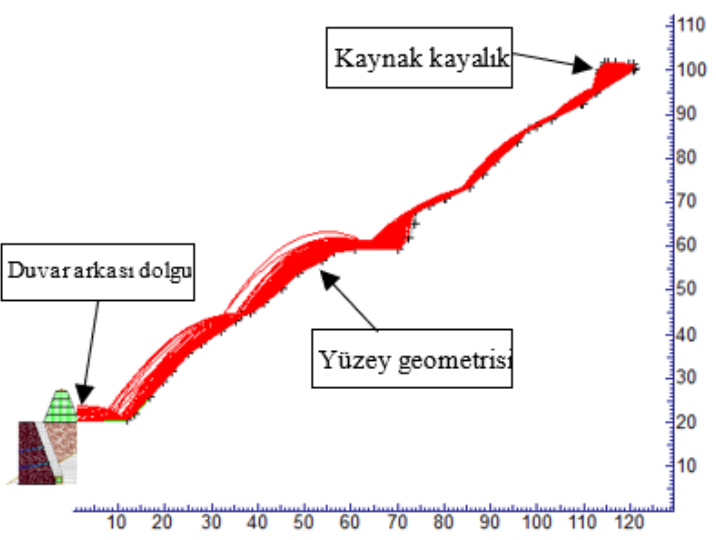

(ii)

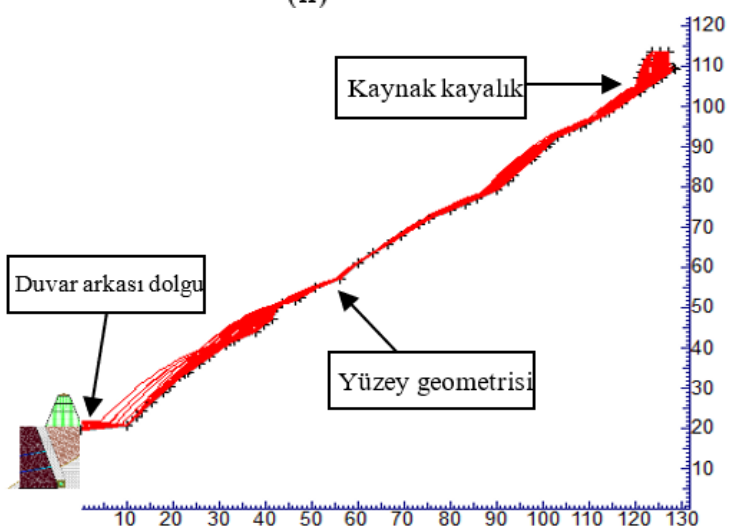

(iv)

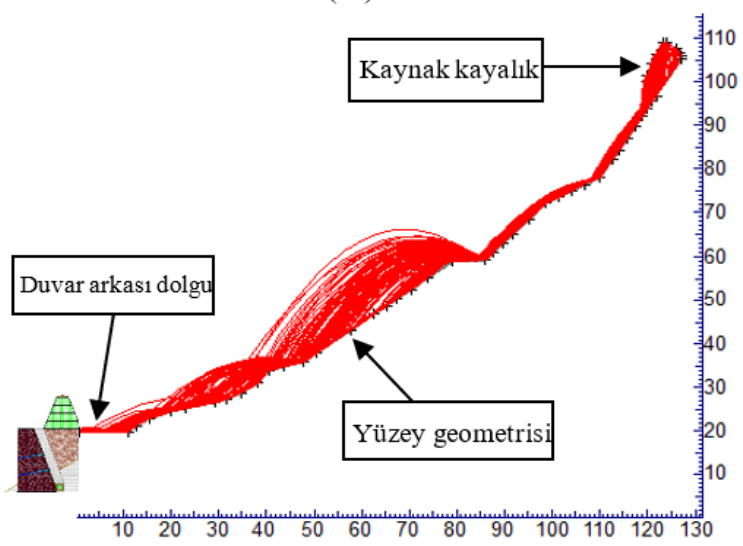

(vi)

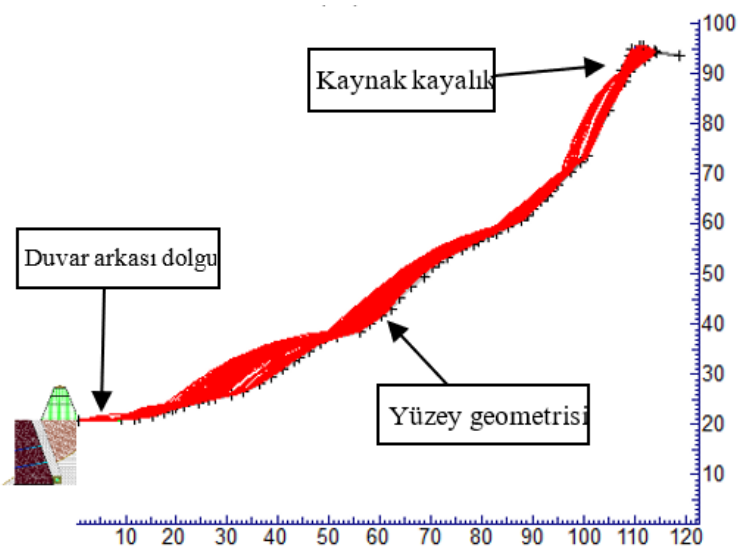

(viii)

Şekil 10: Istinat duvarı ve dolgu yapıldıktan sonra kritik güzergâhlarda kayaların muhtemel hareketleri 


\subsection{Maliyet Analizleri}

Çalışma kapsamında geliştirilen çözüm $6 \mathrm{~m}$ yüksekliğinde taş duvar arkası dolgu ve üzerinde yapılan $3 \mathrm{~m}$ yüksekliğinde toprakarme duvar olarak belirlenmiştir. Bu duvarın enerji sönümleme kapasitesi yaklaşı 7500 kJ'dür. Bu projeye alternatif olarak iki farklı projenin daha maliyeti hesaplanacaktır. Projelerden birincisi $6 \mathrm{~m}$ yüksekliğinde betonarme duvar arkasına dolgu ve üzerine yapılacak 3 metre yüksekliğinde $2000 \mathrm{~kJ}$ enerji kapasiteli çelik bariyer olarak planlanmıştır. Çelik bariyerin ankrajları daha sağlam olması için betonarme duvara soketlenmiştir. Betonarme duvarın boyutları ankraj yükleri de eklenerek hesaplanmıştır. İkinci alternatif proje yalın halde yapılmış $6 \mathrm{~m}$ yüksekliğinde 5000 kJ kapasiteli çelik bariyerdir. Üç imalat için Karayolları Genel Müdürlüğünün (KGM) ve Çevre Şehircilik Bakanlığının (ÇŞB) oluşturduğu pozlar ve fiyatlar kullanılmıştır. Pozu bulunmayan çelik bariyer gibi bazı özel imalatlar için üretici firmalardan fiyat teklifi alınarak yaklaşık maliyet oluşturulmuştur. Nakliyeler fiyatlara eklenerek, kum, duvar taşları, çimento ve donatı gibi malzemelerin $15 \mathrm{~km}$ mesafeden nakledildiği kabul edilmiştir. Fiyatların karşılaştırılması için her bir imalatın 20 metre yapılmasının detayları verilmiştir. Verilen imalat maliyetleri içerisinde taş duvar üzerine toprakarme duvar imalatı Trabzon İl Afet Acil Durum Müdürlüğü tarafından 2019 yılında ihaleye çıkartılmış ve uygulaması bitirilmiştir. Kuruma ait yaklaşık maliyet detayları gizlenebilmesi için imalat detaylarında çeşitli değişikliklere gidilmiş orijinal verilere paralel değerlere sahip yeni veriler çıartılmıştır.

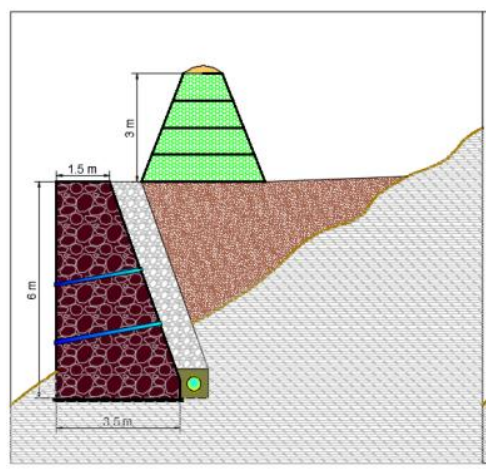

(a)

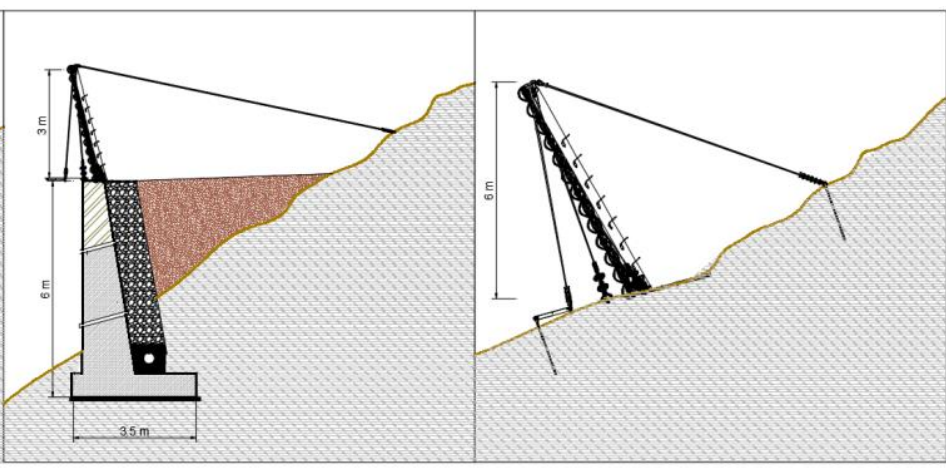

(b) (c)

Şekil 11: Üç alternatif kaya ıslahı önlem yapıları (a) taş istinat duvar üzerine toprakarme, (b) betonarme istinat duvar üzerine çelik bariyer ve (c) çelik bariyer detayları

\section{Bulgular}

Çalışmada toprakarme duvarın, istinat yapısı üzerine yapılması hem maliyet hem de fayda açısından incelenmiş̧ir. İncelemenin yapılabilmesi için örnek bir kaya düşme afeti yaşanan alan için yapılan proje üzerinden gidilmiştir. Bulgular kısmında bilgisayar destekli istatistik analizleri ve maliyet hesaplarının yapımı ile elde edilen veriler verilerek değerlendirmeler yapılacaktır.

\subsection{Analiz verileri}

Düşme ihtimali bulunan kayaların etkiledikleri alanda düşme yönünde 8 adet arazi kesiti çıkartılmıştır. Her bir kesit bilgisayar destekli istatistik programı kullanılarak kaya düşmesi senaryoları incelenmiştir. Kayaların düşme sırasında kazandıkları yükseklik, kinetik enerji ve hız ile ilgili bilgiler araştırılmıştır. Bu bilgiler kesit boyunca elde edilmiştir ancak imalatın yapılacağı Şekil 5'de görülen uygulama alanında elde edilen veriler karşılaştırılmıştır. Tablo 7'de Uygulama alanında oluşan en kritik sıçrama yükseklikleri, kinetik enerjileri ve hızlara sahip 8 kesitin değerleri verilmiştir. Tablo 8 'de uygulama alanına istinat duvarı ve dolgu yapılarak düz alan elde edildikten sonra aynı kesitlerin değerleri verilmiştir.

Tablo 7: Arazinin doğal halindeki kaya düşme analizleri sonucu

\begin{tabular}{|r|c|c|c|c|c|c|c|c|c|}
\hline Kesit No: & i. & ii & iii & iv & v & vi & vii & viii & Ort. \\
\hline Ortalama Eğim (Derece) & $34^{\mathbf{0}}$ & $35^{\mathbf{0}}$ & $37^{0}$ & $36^{\mathbf{0}}$ & $35^{\mathbf{0}}$ & $36^{\mathbf{0}}$ & $34^{\mathbf{0}}$ & $34^{\mathbf{0}}$ & $35.12^{\mathbf{0}}$ \\
\hline Km + m & $0+15$ & $0+30$ & $0+45$ & $0+60$ & $0+75$ & $0+90$ & $0+105$ & $0+120$ & - \\
\hline Siçrama Yüksekliği (m) & 8.25 & $\mathbf{9 . 0 5}$ & 5.75 & 6.89 & 8.15 & 5.25 & 6.38 & 6.20 & 6.99 \\
\hline Toplam Kinetik Enerji (kJ) & 1600 & 1850 & 1780 & $\mathbf{3 1 0 0}$ & 2195 & 1280 & 1485 & 1900 & 1898.75 \\
\hline Hız (m/sn) & 22.75 & 25.20 & 22.15 & $\mathbf{3 1 . 5 2}$ & 28.15 & 20.15 & 21.85 & 25.68 & 24.68 \\
\hline
\end{tabular}


Tablo 8: Duvar arkası oluşturulan düz platform sonrası kaya düşme analizleri sonucu

\begin{tabular}{|r|c|c|c|c|c|c|c|c|c|}
\hline Kesit No: & i. & ii & iii & iv & $\mathbf{v}$ & vi & vii & viii & Ort. \\
\hline Ortalama Ĕ̆im (Derece) & $34^{0}$ & $35^{0}$ & $37^{\circ}$ & $36^{0}$ & $35^{0}$ & $36^{0}$ & $34^{0}$ & $34^{0}$ & $35.12^{\mathbf{0}}$ \\
\hline Km + m & $0+15$ & $0+30$ & $0+45$ & $0+60$ & $0+75$ & $0+90$ & $0+105$ & $0+120$ & - \\
\hline Sıçrama Yüksekliği (m) & 1.41 & 1.53 & 1.30 & $\mathbf{1 . 5 5}$ & 1.09 & 0.83 & 1.18 & 0.65 & 1.19 \\
\hline Toplam Kinetik Enerji (kJ) & 600 & 400 & 715 & $\mathbf{1 0 1 5}$ & 815 & 595 & 750 & 885 & 721.75 \\
\hline Hız (m/sn) & 13.10 & 12.50 & 14.50 & $\mathbf{1 8 . 2 5}$ & 14.88 & 11.37 & 13.20 & 15.25 & 14.13 \\
\hline
\end{tabular}

Tablo 1 ve 2 incelendiğinde, uygulama alanına istinat yapısı ve dolgu yapılması durumunda oluşan ortalama değerlerden, sıçrama yüksekliğinin \%83, kinetik enerjinin \%62 ve hızın \%42 oranında azaldığı görülmüştür. Uygulama alanına istinat yapısı ve dolgu yapılması durumunda oluşan en yüksek değerler incelendiğinde sıçrama yüksekliğinin \%82, kinetik enerjinin \%67 ve hızın \%42 oranında azaldığ 1 görülmüştür. Bu sonuçlarında gösterdiği gibi taş duvar yapılması güvenlik açısından oldukça büyük faydalar sağlamaktadır. Betonarme duvarlar ve kısmen taş duvarlar rijit yapılardır. Çarpma sırasında oluşacak etki ile statik dengeleri bozulabilir veya ağır deformasyonlara maruz kalabilmektedir. Bu nedenle arkalarına yapılacak dolgu bu etkilerden duvarları korumaktadır. Ayrıca dolgu malzemesinin iyi seçilmesi durumunda düşen kayaların saplanarak enerjisinin sönümlenmesini de sağlayacaktır. Bu çalışmada dolgu malzeme tipi incelenmemiştir. Ancak gelecek çalışmalarda bu tarz bir inceleme yapılması oldukça faydalı olacağı düşünülmektedir.

\subsection{Fayda Maliyet Hakkında Bulgular}

Aşağıdaki tablolarda 3 farklı imalat tipi için hazırlanan yaklaşık maliyetler bulunmaktadır. Tablo 9'da uygulaması tamamlanmış olan taş duvar üzere toprakarme duvarın 20 metre yapılmasının maliyeti verilmiştir. Taş duvar arkasında dolgu, drenaj yapıları ve toprakarme duvar arkası şev düzenleme gibi detaylar da fiyata eklenmiştir.

Tablo 9: 6 m taş duvar arkası dolgu ve üzerine $3 m$ yüksekliğinde toprakarme duvar maliyeti

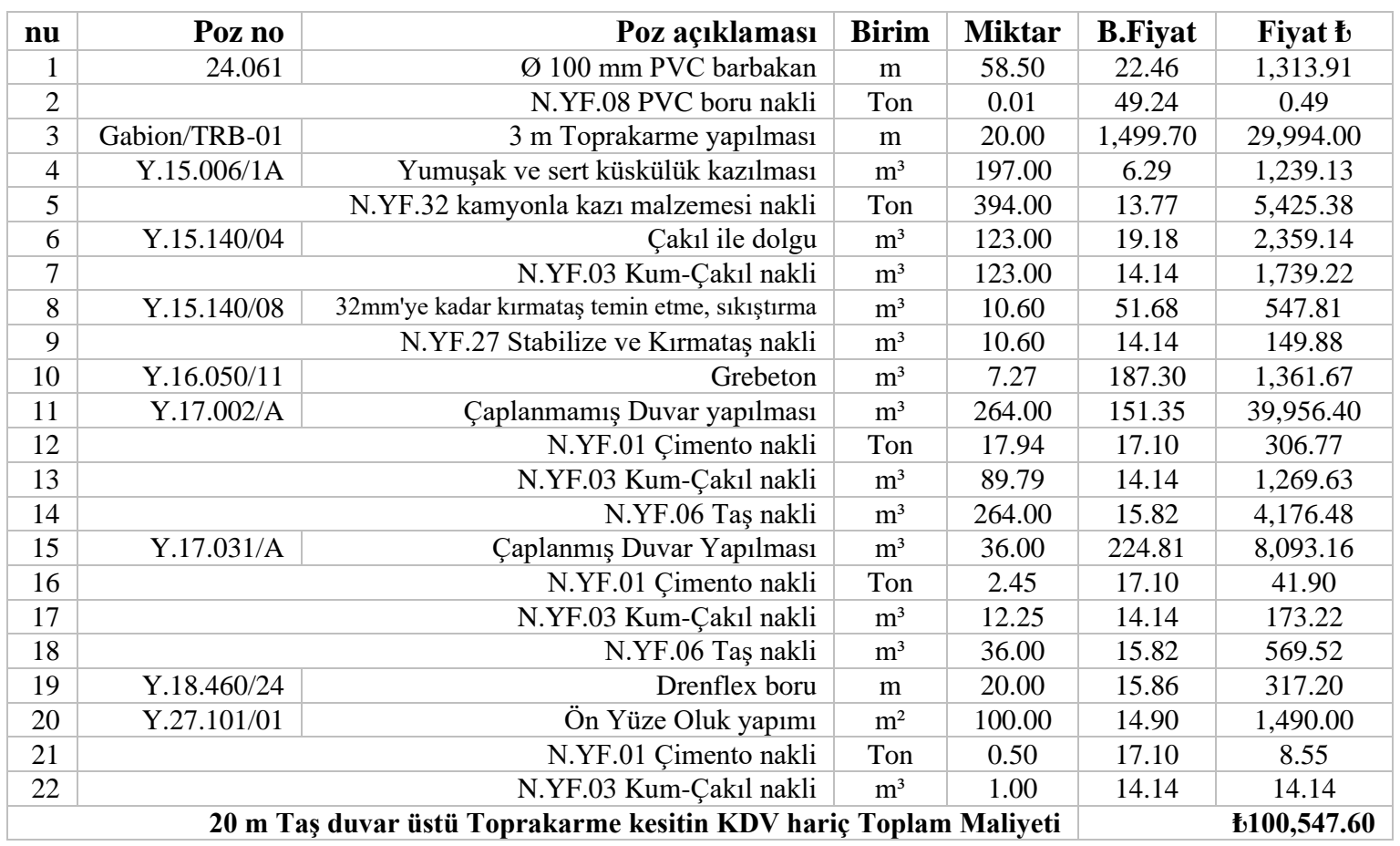

Betonarme üzeri çelik bariyer yapılması ile ilgili yaklaşık maliyet bilgisi Tablo 10'da verilmiştir. Bazı pozların nakliyeleri poz fiyatı içerisinde verilmiştir. Çelik bariyer duvara ankraj olacak şekilde planlanmıştır. Çelik bariyer ile ilgili 3 farklı firmadan fiyat teklifi alınmış ve ortalama ücreti yaklaşı maliyete özel poz olarak eklenmiştir. 
Tablo 10: Betonarme duvar üzeri çelik bariyer yaklaşık maliyeti

\begin{tabular}{|c|c|c|c|c|c|c|}
\hline$\underline{\text { nu }}$ & $\underline{\text { Poz no }}$ & $\underline{\text { Poz acıklaması }}$ & $\underline{\text { Birim }}$ & $\underline{\text { Miktar }}$ & $\underline{\text { B.Fiyat }}$ & Fiyat $\mathbf{E}$ \\
\hline 1 & 24.061 & Ø $100 \mathrm{~mm}$ PVC barbakan & $\mathrm{m}$ & 12.00 & 22.46 & 269.52 \\
\hline 2 & & N.YF.08 PVC boru nakli & Ton & 0.01 & 49.24 & 0.49 \\
\hline 4 & N.YF.32 Şantiye sın & rları dışına kamyonla kazı malzemesi nakli & Ton & 394.00 & 13.77 & $5,425.38$ \\
\hline 5 & Y.15.140/04 & Çakıl ile dolgu & $\mathrm{m}^{3}$ & 123.00 & 19.18 & $2,359.14$ \\
\hline 6 & & N.YF.03 Kum-Çakıl nakli & $\mathrm{m}^{3}$ & 123.00 & 14.14 & $1,739.22$ \\
\hline 8 & & N.YF.27 Stabilize ve Kırmataş nakli & $\mathrm{m}^{3}$ & 10.60 & 14.14 & 149.88 \\
\hline 9 & Y.16.050/11 & Grebeton & $\mathrm{m}^{3}$ & 7.27 & 187.30 & $1,361.67$ \\
\hline 10 & Y.21.051/C11 & Yapı İskelesi & $m^{2}$ & 360.00 & 12.90 & $4,644.00$ \\
\hline 11 & Y.21.001/03 & Betonarme Kalıp Yapılması & $\mathrm{m}^{2}$ & 244.00 & 57.48 & $14,025.12$ \\
\hline 12 & Y.16.050/15 & C $25 / 30$ beton Temini nakliyesi dökülmesi & $\mathrm{m}^{3}$ & 128.70 & 220.11 & $28,328.16$ \\
\hline \multicolumn{5}{|c|}{20 m Betonarme duvar üstü Çelik Bariyer kesitin KDV hariç Toplam Maliyeti } & \multicolumn{2}{|c|}{$\mathbf{E 2 5 6 , 7 1 4 . 4 0}$} \\
\hline
\end{tabular}

Maliyet karşılaştırması için hazırlanan son yaklaşık maliyet sadece çelik bariyer kullanılması ile ilgilidir. Çelik bariyerler özel taleplere karşılık 12 m’ye kadar yapılabilmektedir. Ancak bu çalışmada sadece piyasada kullanılan ve firmaların birçoğunun ürettiği $6 \mathrm{~m}$ yüksekliğe sahip $5000 \mathrm{~kJ}$ bariyerin fiyatı verilmiştir. Tablo 11'de yaklaşı maliyeti verilen proje için yeterli olmayan bu imalat sadece karşılaştırma amaçlı eklenmiştir.

Tablo 11: Çelik bariyer yapılması maliyeti

\begin{tabular}{|c|c|c|c|c|c|c|}
\hline$\underline{\text { nu }}$ & $\underline{\text { Poz no }}$ & Poz acıklaması & $\underline{\text { Birim }}$ & Miktar & B.Fiyat & Fiyat $€$ \\
\hline 1 & Bariyer $6 \mathrm{~m} / 5000 \mathrm{~kJ}$ & 6 metre yüksekliğinde $5000 \mathrm{~kJ}$ Çelik Bariyer & $\mathrm{m}$ & 20.00 & $19,756.08$ & $395,121.60$ \\
\hline \multicolumn{5}{|c|}{6 m yüksekliğinde 5000 kJ enerji kapasitesine sahip Çelik Bariyerin KDV hariç Maliyeti } & \multicolumn{2}{|c|}{$\mathbf{6 3 9 5 , 1 2 1 . 6 0}$} \\
\hline
\end{tabular}

Tablolar incelendiğinde, taş duvar üzerine toprakarme duvar yapılması, betonarme duvar üzerine çelik bariyer yapılmasından \%60.8 oranında daha az maliyetlidir. Ayrıca sadece çelik bariyer yapılmasından $\% 74.5$ oranında daha az maliyetli olduğu görülmektedir. Maliyetinin az olmasının yanı sıra, toprakarme duvarların en az $7500 \mathrm{~kJ}$ enerji kapasitelerinin bulunması diğer alternatiflerinden enerji sönümleme kapasitesi olarak daha avantajlı yani daha güvenilir olduğunu göstermektedir. Toprakarme duvarlar aynı anda birden çok taş çarpması durumunda da sabit enerji kapasitelerini korumaya devam edebilmektedirler. Taş duvar ve betonarme duvarın arkasına yapılacak dolgu ayrıca gelen kaya için enerji kırılması etkisi yapacak bir alan oluşturduğundan her iki türde yapılacak sslah projesi de sadece çelik bariyer yapılmasından daha üstün güvenlik sağlamaktadır. Toprakarme duvarlar, kaya çarpması sonrasında çok az deformasyona uğramaktadır. Buna karşılık çelik bariyerlerde kapasitelerinin altında çarpan kayalarda bile Şekil 12'de görüldüğü gibi deformasyonlar oluşmakta ve tasarım boyunu kısaltmaktadır. Bu nedenle peş peşe gelen kayalarda, kayaların sıçrama yüksekliği nedeniyle bariyer üzerinden aşabilme ihtimali bulunmaktadır. Toprakarme bariyerlerde enerji kapasitesini aşmadığı müddetçe defalarca kaya çarpması olması hatta kayaların beraber gelmesi durumunda bile boyda azalma olmamaktadır.
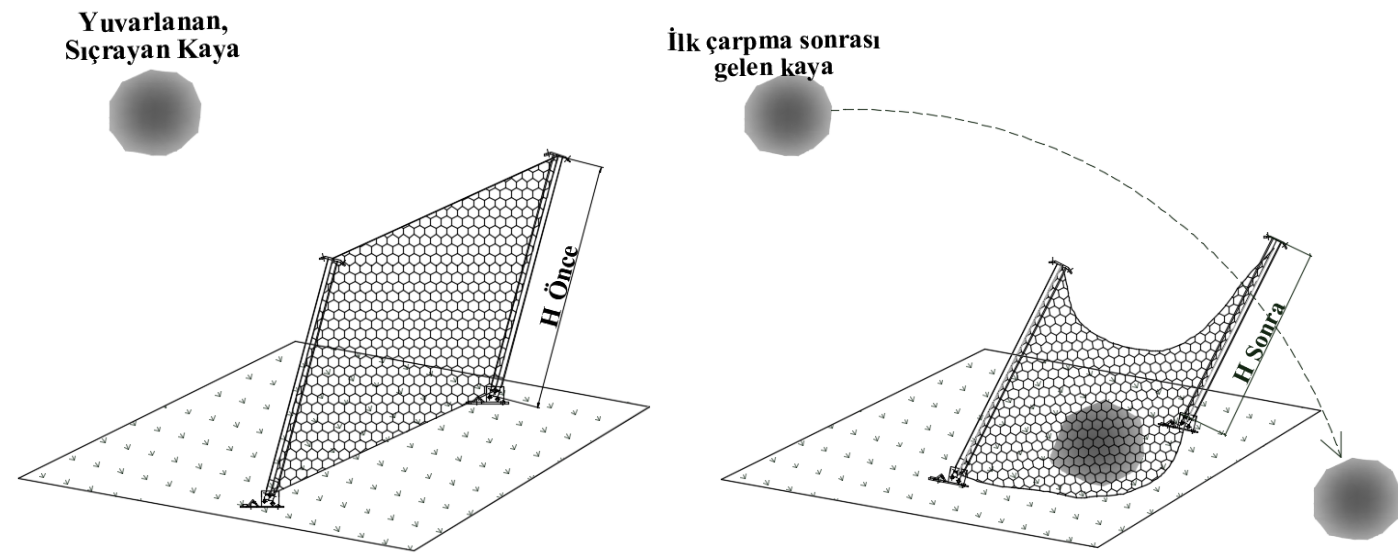

Şekil 12: Kaya çarpması sonrasında çelik bariyerlerde boy azalması olmakta 
Toprakarme duvarlar çelik bariyerlere göre bakım onarım masrafları açısından da daha üstündür. Toprakarme duvarlar genellikle ömürleri boyunca temizleme işlemi dışında bakım onarım ihtiyacı duymazlar. Ancak çelik bariyerlerde belirli bir enerji kapasitesine sahip çarpmalar sonrasında, Şekil 13'de görülen dissipatör denen enerji sönümleyicilerinin değişmesi gerekmektedir. Dissipatörlerin ithal ve patentli ürün olması nedeniyle yüksek maliyetlere sahip olması çelik bariyerler için oldukça büyük bir dezavantajdır. Dissipatörün değişmemesi durumunda her kaya çarpması sonrasında temizlik yapılmış olsa da bariyerin enerji kapasitesi azalmakta, bir süre sonra tasarım enerji seviyesinin altına inmektedir.

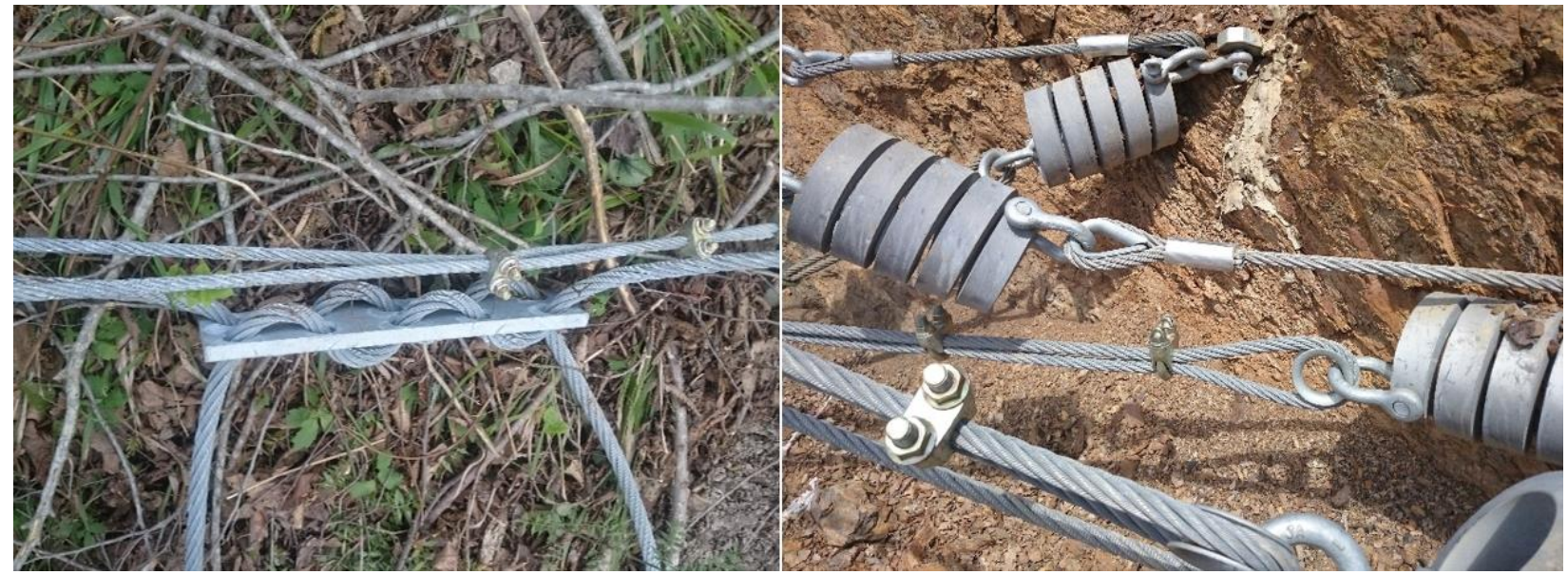

Şekil 13: Kaya çarpması sonrasında değişen enerji sönümleyicilerin farklı türleri

Bu çalışma kapsamında incelenen ve farklı bir metot ile yapılması için araştırma yapılan imalat Trabzon İli Maçka İlçesi Güney Mahallesinde Trabzon İl Afet ve Acil Durum Müdürlüğü tarafından ihale edilerek inşa edilmiştir. Bitirilen taş duvar arkasında dolgu ve üzerinde Toprakarme Duvar imalatı ile ilgili fotoğraf aşağıda Şekil 14'de verilmiştir.

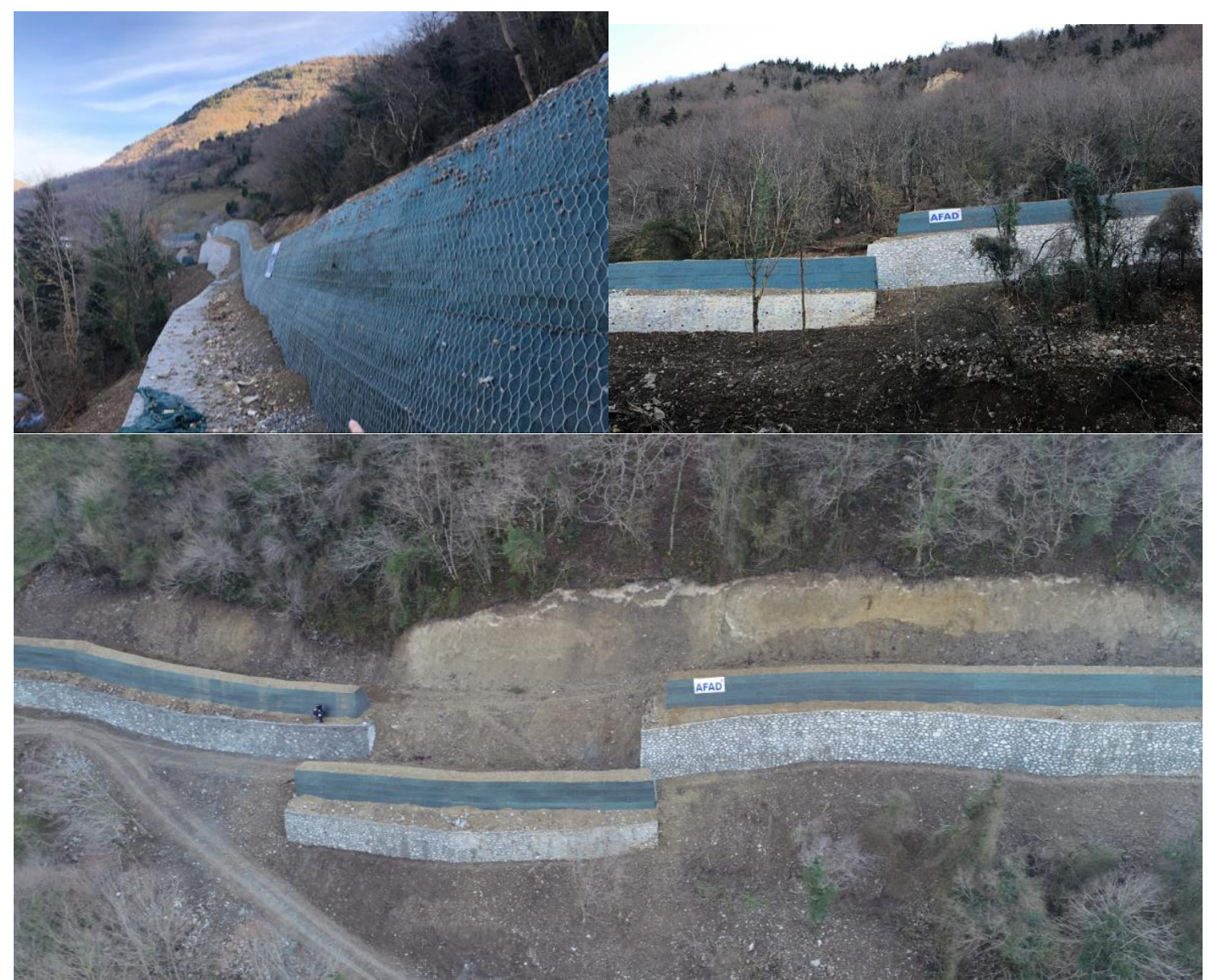

Şekil 14: Trabzon Maçka ilçesi güney mahallesinde taş duvar üzerine yapılmış toprakarme duvar imalatı 


\section{Sonuçlar}

Çalışmada uygulanmış bir proje üzerinden, istinat yapısı üzerine yapılmış toprakarme duvar fayda maliyet açısından incelenmiştir. Bulgular kısmında bilgisayar destekli analiz programlarının verileri ile yapının faydası irdelenmiş, daha sonra maliyet karşılaştırmaları yapılmıştır. Elde edilen veriler ışığında şu sonuçlara ulaşılmıştır:

- Toprakarme duvarlar, tasarım özellikleri nedeniyle geniş bir taban alanına ihtiyaç duymaktadır. Eğimli arazilerde tabanın oturabileceği bir alan oluşturmak için taş duvar gibi çeşitli istinat yapıları yapıldı̆̆ında toprakarme duvarlar güvenli şekilde uygulanabilmektedir. Ancak iyi bir jeolojik etüt ve harita bilgisi olması yapının güvenliği için oldukça önemlidir.

- Kaya düşmesi güzergâhında imalat yapılacak bölgede duvar ve dolgu olmasının, olası bir kaya düşmesinde sıçrama yüksekliğini \%83, kinetik enerjiyi \%62 ve hızı \%42 oranında azalttığı görülmüştür. Bu durum üzerine yapılacak önlem yapısının tasarım özelliklerini dolayısıyla maliyetini azaltacaktır. Ayrıca daha güvenilir önlem projeleri oluşmasını sağlayacaktır. Toprakarme bariyerler taş duvarların arkasına yapılabilen yapılar olmasına rağmen çelik bariyerlerin genellikle betonarme duvarların arkasına yapılması gerekmektedir. Zira ankraj için dolgu alanlarının kullanılması sıkıntılar doğurabileceğinden, betonarmeye ankraj yapılması projenin güvenliğini artırmaktadır.

- Taş duvar üzerine yapılan toprakarme duvarların ilk yapım maliyetleri, aynı boya sahip betonarme üzeri çelik bariyere göre \%60.8, sadece çelik bariyer uygulamasından \%74.5 oranında daha az maliyetlidir. Ayrıca toprakarme duvarların tasarım enerji kapasitelerinin çelik bariyere göre yaklaşık 3 kat daha fazla olması, boyunun kaya çarpmaları nedeniyle azalmıyor olması ve daha hızlı çarpmalara karşı dayanıklı olması nedeniyle hem fayda hem de maliyet açısından daha avantajlı olduğunu göstermektedir.

- Toprakarme bariyer uygulanırken, yerli ve herkes tarafından temin edilebilir ürünler olması nedeniyle ihale usulü imalatlarda yükleniciler tarafından daha fazla fiyat kırımı yapılabilmektedir. Çelik bariyerler ise genellikle birkaç ülke tarafından üretilen patentli ürünler olması nedeniyle pahalı ithal ürünlerdir. Ayrıca çelik bariyerlerin bakım onarım ihtiyaçları yüksektir. Çelik bariyerler bakım onarım ihtiyacı duyan kaya ıslahı yöntemleri olduklarından da dezavantajlıdır. İmalat yapılan alanların ulaşılması zor alanlar olduğu düşünüldügüunde bakım onarım maliyetlerinin de ekstra külfet oluşturmayacağı imalatların seçilmesi daha avantajlı olacaktır. Son olarak toprakarme bariyerler kısa sürede üzerlerinde yetişen bitki nebatat nedeniyle doğaya daha kolay adapte olmaktadır.

\section{Teşekkür}

Bu çalışma kapsamında bilgi ve veri paylaşımında bulunan Trabzon İl Afet ve Acil Durum Müdürlüğü ve Dynamica Mühendislik yetkililerine teşekkür ederiz.

\section{Kaynaklar}

Agliardi F., Crosta G.B., Frattini P., (2009), Integrating rockfall risk assessment and countermeasure design by 3D modeling techniques, Natural Hazards and Earth System Sciences, 9(4), 1059-1073.

ASTM, (2011), Standard test method for direct shear test of soils under consolidated drained conditions, D3080/D3080M. ASTM International, West Conshohocken, United States.

Brunet G., Giacchetti G., Bertolo P., Peila D., (2009), Protection from high energy rock-fall impacts using Terramesh embankment: design and experiences, Proceedings of the 60th Highway Geology Symposium, Buffalo, New York, ss.107-124.

Çelik M., Seferoğlu M.T., Seferoğlu A.G., Akpınar M.V., (2016), Rehabilitation Methods, Challenges, Cost Benefit Analysis of Disaster Area Exposed due to Rockfalls in Trabzon Province, Doğal Afet ve Afet Yönetimi Sempozyumu (DAAYS'16), 2-4 Mart, Karabük, Türkiye.

Deer D.U., Miller R.P., (1966), Engineering Classification and Index Properties for Intact Rock: Technical Report AFNL-TR-65-116, Air Force Weapons Laboratory, New Mexico, USA.

Descoeudres F., (1997), Aspects géomécaniques des instabilités de falaises rocheuses et des chutes de blocs, Publications De La Société Suisse De Mécanique Des Sols et Des Roches 135, 3-11.

Hutchinson J.N., (1988), Morphological and Geotechnical Parameters of Landsline in Relation to Geology and Hydrogeology, 5th International Symposium on Landslides, 1, 3-35, Lausanne, USA.

Kaya A., Demirbaş C., Dağ S., (2018), Gündoğan (Ardeşen-Rize) Köyü Yerleşim Alanındaki Yamaç Duraysızlı̆̆ının Jeoteknik Açıdan Incelenmesi, Doğal Afetler ve Çevre Dergisi, 4(2), 221-235.

Keçeli A., (1990), Sismik Yöntemlerle Müsaade Edilebilir Dinamik Zemin Taşıma Kapasitesi ve Oturmasının Saptanması, Jeofizik, 4(2), 83-92.

Lambert S., Bourrier F., (2013), Design of Rockfall Protection Embankments: a Review, Engineering Geology, 154, 77-78.

Masuya H., Amanuma K., Nishikawa Y., Tsuji T., (2009), Basic rockfall simulation with consideration of vegetation and application to protection measure, Natural Hazards and Earth System Sciences, 9(6), 1835-1843.

Moistures S.A., (1982), Method for Classification of Soils for Engineering Purposes (D 2487-69), 299 Method for Diamond Core Drilling for Site Investigation.

Peila D., Oggeri C., Castiglia C., (2007), Ground reinforced embankments for rockfall protection: design and evaluation of full scale tests, Landslides Investigations and Mitigation, 4(3), 255-265. 
Peila D., Pelizza S., Sassudelli F., (1998), Evaluation of behaviour of rockfall restraining nets by full scale tests, Rock Mech. Rock Eng., 31(1), 1-24.

Rocscience Inc., (2013), RocFall 5.0.12, https://www.rocscience.com/software/rocfall [Erişim 10 Şubat 2020].

Ronco C., Oggeri C. and Peila D., (2009), Design of reinforced ground embankments used for rockfall protection, Natural Hazards and Earth System Sciences, 9(4), 1189-1199.

Turner A.K., Schuster R.L., (2012), Rockfall Characterization and Control, Transportation Research Board, National Academy of Sciences, Washington D.C., USA, 658ss.

Varnes D.J., (1978), Slope Movement Types and Processes, Spetial Report, In: R.L. Schuster and R.J. Krizek, Eds., Landslides, Analysis and Control, National Academy of Sciences, 176, 11-33. 